University of Nebraska - Lincoln

DigitalCommons@University of Nebraska - Lincoln

2005

\title{
THE COMPOSITION OF COEXISTING JAROSITE-GROUP MINERALS AND WATER FROM THE RICHMOND MINE, IRON MOUNTAIN, CALIFORNIA
}

\author{
Heather E. Jamieson \\ Queen's University - Kingston, Ontario, jamieson@geol.queensu.ca \\ Clare Robinson \\ Queen's University - Kingston, Ontario \\ Charles N. Alpers \\ U.S. Geological Survey \\ D. Kirk Nordstrom \\ U.S. Geological Survey \\ Alexei Poustovetov \\ Queen's University - Kingston, Ontario \\ See next page for additional authors \\ Follow this and additional works at: https://digitalcommons.unl.edu/usgsstaffpub \\ Part of the Earth Sciences Commons
}

Jamieson, Heather E.; Robinson, Clare; Alpers, Charles N.; Nordstrom, D. Kirk; Poustovetov, Alexei; and Lowers, Heather A., "THE COMPOSITION OF COEXISTING JAROSITE-GROUP MINERALS AND WATER FROM THE RICHMOND MINE, IRON MOUNTAIN, CALIFORNIA" (2005). USGS Staff -- Published Research. 475.

https://digitalcommons.unl.edu/usgsstaffpub/475

This Article is brought to you for free and open access by the US Geological Survey at DigitalCommons@University of Nebraska - Lincoln. It has been accepted for inclusion in USGS Staff -- Published Research by an authorized administrator of DigitalCommons@University of Nebraska - Lincoln. 
Authors

Heather E. Jamieson, Clare Robinson, Charles N. Alpers, D. Kirk Nordstrom, Alexei Poustovetov, and Heather A. Lowers

This article is available at DigitalCommons@University of Nebraska - Lincoln: https://digitalcommons.unl.edu/ usgsstaffpub/475 


\title{
THE COMPOSITION OF COEXISTING JAROSITE-GROUP MINERALS AND WATER FROM THE RICHMOND MINE, IRON MOUNTAIN, CALIFORNIA
}

\author{
HEATHER E. JAMIESON ${ }^{\S}$ AND CLARE ROBINSON \\ Department of Geological Sciences, Queen's University, Kingston, Ontario K7L 3N6, Canada \\ CHARLES N. ALPERS \\ U.S. Geological Survey, Placer Hall, 6000 J Street, Sacramento, California 95819, U.S.A. \\ D. KIRK NORDSTROM \\ U.S. Geological Survey, 3215 Marine Street, Boulder, Colorado 80303, U.S.A.
}

ALEXEI POUSTOVETOV

Department of Geological Sciences, Queen's University, Kingston, Ontario K7L 3N6, Canada

HEATHER A. LOWERS

U.S. Geological Survey, Denver Federal Center, Mail Stop 973, Denver, Colorado 80225, U.S.A.

\begin{abstract}
Jarosite-group minerals accumulate in the form of stalactites and fine-grained mud on massive pyrite in the D drift of the Richmond mine, Iron Mountain, California. Water samples were collected by placing beakers under the dripping stalactites and by extracting pore water from the mud using a centrifuge. The water is rich in $\mathrm{Fe}^{3+}$ and $\mathrm{SO}_{4}{ }^{2-}$, with a pH of approximately 2.1, which is significantly higher than the extremely acidic waters found elsewhere in the mine. Electron-microprobe analysis and $\mathrm{X}$-ray mapping indicate that the small crystals $(<10 \mu \mathrm{m}$ in diameter) are compositionally zoned with respect to $\mathrm{Na}$ and $\mathrm{K}$, and include hydronium jarosite corresponding to the formula $\left(\mathrm{H}_{3} \mathrm{O}\right)_{0.6} \mathrm{~K}_{0.3} \mathrm{Na}_{0.1} \mathrm{Fe}^{3+}{ }_{3}\left(\mathrm{SO}_{4}\right)_{2}(\mathrm{OH})_{6}$. The proton-microprobe analyses indicate that the jarosite-group minerals contain significant amounts of $\mathrm{As}, \mathrm{Pb}$ and $\mathrm{Zn}$, and minor levels of $\mathrm{Bi}, \mathrm{Rb}, \mathrm{Sb}, \mathrm{Se}, \mathrm{Sn}$ and Sr. Speciation modeling indicates that the drip waters are supersaturated with respect to jarosite-group minerals. The expected range in composition of jarosite-group solid-solution in equilibrium with the pore water extracted from the mud was found to be consistent with the observed range in composition.
\end{abstract}

Keywords: jarosite, acid mine-drainage, aqueous speciation, solid solution, Richmond mine, California.

\section{SOMMAIRE}

Nous décrivons des minéraux du groupe de la jarosite qui s'accumulent sous forme de stalactites et de boues à granulométrie fine sur la pyrite massive le long de la gallerie d'avancement D de la mine Richmond, à Iron Mountain, en Californie. Nous avons prélevé des échantillons d'eau en plaçant des béchers sous les stalactites dégouttantes et en extrayant l'eau des pores de la boue avec une centrifugeuse. L'eau est riche en $\mathrm{Fe}^{3+}$ et $\mathrm{SO}_{4}{ }^{2-}$, avec un $\mathrm{pH}$ d'environ 2.1, ce qui est nettement plus élevé que dans les eaux extrêmement acides trouvées ailleurs dans cette mine. Les résultats d'analyses à la microsonde électronique et des cartes de répartition d'éléments indiquent que les petits cristaux, moins de $10 \mu \mathrm{m}$ de diamètre, sont zonés par rapport à Na et $\mathrm{K}$, et coexistent avec une hydronium jarosite de composition $\left(\mathrm{H}_{3} \mathrm{O}\right)_{0.6} \mathrm{~K}_{0.3} \mathrm{Na}_{0.1} \mathrm{Fe}^{3+}{ }_{3}\left(\mathrm{SO}_{4}\right)_{2}(\mathrm{OH})_{6}$. D'après les résultats d'analyses par microsonde protonique, les minéraux du groupe de la jarosite contiennent des teneurs importantes de $\mathrm{As}, \mathrm{Pb}$ et $\mathrm{Zn}$, et des niveaux mineurs de $\mathrm{Bi}, \mathrm{Rb}, \mathrm{Sb}, \mathrm{Se}$, $\mathrm{Sn}$ et $\mathrm{Sr}$. Les modèles de spéciation montrent que l'eau dégouttant des stalactites est sursaturée par rapport aux minéraux du groupe de la jarosite. L'intervalle compositionnel prédit des minéraux du groupe de la jarosite en équilibre avec l'eau des pores extraite de la boue concorde avec l'intervalle observé.

Mots-clés: eau d'exhaure acide, spéciation aqueuse, solution solide, mine Richmond, Californie.

$\S \quad$ E-mail address: jamieson@geol.queensu.ca 


\section{INTRODUCTION}

The inactive base-metal mines at Iron Mountain, California (Fig. 1) are well known for producing extremely acidic drainage (including waters with $\mathrm{pH}$ less than 0) and a variety of efflorescent iron sulfate minerals (Nordstrom \& Alpers 1995, 1999a, Nordstrom et al. 2000, Alpers et al. 2003). Gold, silver, copper, zinc, iron, and pyrite (for production of sulfuric acid) were extracted from volcanogenic massive sulfide deposits at Iron Mountain from the 1860s to 1962. Waters currently draining the Richmond mine have particularly high concentrations of dissolved sulfate and metals as a result of the vigorous oxidation of massive pyrite that remains within the mine (Nordstrom \& Alpers 1995). Massive pyritic ore (95-98\% pyrite), ready availability of gaseous oxygen and water in porous and unsaturated conditions of the mine workings, the presence of iron- and sulfur-oxidizing bacteria (e.g., Edwards et al. 2000, Robbins et al. 2000), and elevated temperatures (observed to be $28-47^{\circ} \mathrm{C}$ and estimated to be as high as $60-70^{\circ} \mathrm{C}$ ) caused by exothermic oxidation of pyrite combine to form optimal conditions for sulfide oxidation. The hydrothermally altered felsic metavolcanic host-rock (the Balaklala Formation of Devonian age; Kinkel et al. 1956) provides little acid-neutralization capacity. Waters flowing from the Richmond portal have $\mathrm{pH}$ values around 0.5 and drips in the Richmond mine have $\mathrm{pH}$ values as low as -3.6 (Nordstrom \& Alpers 1999a, Nordstrom et al. 2000).

It has been observed generally that jarosite-group minerals will precipitate from mine drainage if the $\mathrm{pH}$ is relatively low, Eh is high and adequate sulfate is available (Bigham \& Nordstrom 2000). However, a quantitative relationship between the composition of acid-sulfate waters and jarosite solid-solutions under field conditions has not been described, mainly because few mineral samples and coexisting waters have been characterized, such as the subject of the present study.

\section{Sulfate Minerals at the Richmond Mine}

Within the underground workings of the Richmond mine, abundant efflorescences of iron sulfate form by oxidation and evaporation of acidic mine-waters. These include soluble $\mathrm{Fe}^{2+}$ sulfates such as melanterite, szomolnokite, mixed $\mathrm{Fe}^{2+}-\mathrm{Fe}^{3+}$ sulfates such as copiapite, voltaite, römerite, and some $\mathrm{Fe}^{3+}$ sulfates such as coquimbite and rhomboclase (Table 1). The repeated dissolution and precipitation of these secondary sulfate minerals are a significant contributing factor to the extremely poor quality of water at Iron Mountain; these soluble minerals store $\mathrm{Fe}^{2+}, \mathrm{SO}_{4}$, potentially hazardous elements such as $\mathrm{As}, \mathrm{Cd}, \mathrm{Cu}$ and $\mathrm{Zn}$, as well as acidity (in the form of $\mathrm{H}_{3} \mathrm{O}^{+}$) and $\mathrm{Fe}^{3+}$ (an oxidant) during dry seasons, and release them during wet seasons (Alpers et al. 1992, 1994, Nordstrom \& Alpers 1999a, Jamieson et al. 1999). The sudden increase in dissolved metals after winter rainfall events has been attributed to the dissolution of the soluble metal sulfate salts (Alpers et al. 1994). This "first flush" phenomenon has also been noted at other mine-waste sites (Jambor et al. 2000).

In July 1998, jarosite-group minerals were discovered on a stope wall (approximately $5 \mathrm{~m}^{2}$ ) within the Richmond mine. Much of the massive, fine-grained pyrite on the stope wall was covered with moist and pasty jarosite-group minerals and stalactites that were actively dripping acidic water (Robinson 2000, Robinson et al. 2000). This discovery provided the opportunity to collect and analyze samples of coexisting water and the jarosite-group minerals. In this paper, we present those results and describe how they can be used to quantify the relationship between acid waters saturated with one or more jarosite-group minerals and the composition of the jarosite-group mineral(s) that precipitate(s) from those solutions.

Jarosite-group minerals are relatively common in mine waste, but had not been noted as a secondary mineral within the Richmond mine workings prior to 1998, most likely because the conditions are generally too acidic $(\mathrm{pH}<1)$. However, Alpers et al. (1989) analyzed jarosite-group minerals that had precipitated from effluent waters emanating from the Richmond mine and the nearby Hornet mine after the water samples had been stored for 11 to 13 years. It was assumed that at the time of collection, the waters were somewhat undersaturated with jarosite-group minerals, and subsequent oxidation of dissolved $\mathrm{Fe}^{2+}$ caused precipitation. Alpers et al. (1989) used the composition of the coexisting jarosite and aqueous solutions to calculate a Gibbs free energy value for an intermediate member of the jarosite solid-solution corresponding to $\left[\mathrm{K}_{0.77} \mathrm{Na}_{0.03}\left(\mathrm{H}_{3} \mathrm{O}\right)_{0.20}\right] \mathrm{Fe}^{3+}{ }_{3}\left(\mathrm{SO}_{4}\right)_{2}(\mathrm{OH})_{6}$.

\section{JAROSITE-GROUP MinERALS In Mine-Waste ENVIRONMENTS}

Jarosite-group minerals are commonly found as a secondary phases formed from the oxidation of sulfide deposits and associated with acid rock-drainage (Alpers \& Brimhall 1989, Jambor 1994, Bigham

TABLE 1. SOME IRON SULFATES FROM THE RICHMOND MINE, WITH THEIR IDEAL FORMULA

$$
\begin{aligned}
& \mathrm{Fe}^{2+} \text { sulfates } \\
& \text { Melanterite } \mathrm{Fe}^{2+} \mathrm{SO}_{4} \cdot 7 \mathrm{H}_{2} \mathrm{O} \\
& \text { Szomolnokite } \mathrm{Fe}^{2-} \mathrm{SO}_{4} \cdot \mathrm{H}_{2} \mathrm{O} \\
& \mathrm{Fe}^{2+}-\mathbf{F e}^{3+} \text { sulfates } \\
& \mathrm{Fe}^{3+} \text { sulfates }
\end{aligned}
$$


1994, Nordstrom \& Alpers 1999b, Dutrizac \& Jambor 2000, Jambor et al. 2000, Stoffregen et al. 2000). The jarosite group of minerals includes members of the alunite supergroup with the general formula $D G_{3}\left(\mathrm{TO}_{4}\right)_{2}\left(\mathrm{OH}, \mathrm{H}_{2} \mathrm{O}\right)_{6}$, in which $G$ represents $\mathrm{Fe}^{3+}>$ $\mathrm{Al}^{3+}$ and $\mathrm{SO}_{4}$ is greater or equal to $75 \%$ of total $\mathrm{TO}_{4}$ (Jambor 1999). Most samples of natural jarositegroup minerals are considered to be a solid solution of jarosite sensu stricto, $\mathrm{KFe}^{3+}{ }_{3}\left(\mathrm{SO}_{4}\right)_{2}(\mathrm{OH})_{6}$, natrojarosite, $\mathrm{NaFe}^{3+}{ }_{3}\left(\mathrm{SO}_{4}\right)_{2}(\mathrm{OH})_{6}$, and hydronium jarosite, $\left(\mathrm{H}_{3} \mathrm{O}\right) \mathrm{Fe}^{3+}{ }_{3}\left(\mathrm{SO}_{4}\right)_{2}(\mathrm{OH})_{6}$. Hydronium jarosite likely forms under conditions of extremely rapid oxidation of sulfide (Kubisz 1961, Dutrizac \& Jambor 2000) or where availability of $\mathrm{Na}$ and $\mathrm{K}$ is low. Brophy \& Sheridan (1965) showed that a continuous solid-solution exists between the end members jarosite, natrojarosite and hydronium jarosite as a result of element substitution under low-temperature and low-pressure conditions. The presence of hydronium $\left(\mathrm{H}_{3} \mathrm{O}\right)^{+}$is usually inferred from low alkali content in the mineral, as it is difficult to measure directly (Alpers et al. 1989, Stoffregen et al. 2000). On the basis of an interpretation of singlecrystal X-ray-diffraction data on synthetic hydronium jarosite, Majzlan et al. (2004) concluded that the $D$ site in jarosite-group minerals may not be fully occupied, such that the hydronium content reported by difference should be considered a maximum value.

The available data from field and laboratory studies indicate that jarosite-group minerals precipitate from waters in the $\mathrm{pH}$ range of 1 to 3 (Zotov 1970, van Everdingen et al. 1985, Alpers et al. 1989, Baron \& Palmer 1996).

\section{SAMPle Collection}

Mineral and water samples were collected inside the Richmond mine in July 1998. Although underground mining ceased in the 1950s, restoration of the Richmond adit in the early 1990s allowed entry to some of the stopes through a well-lit and ventilated tunnel approximately 400 meters long and 2 to 3 meters in diameter. Four unventilated drifts (A, B, C and D) branch off from the end of this tunnel. Unstable wallrock and poor quality of the air prevented exploration further than approximately $20 \mathrm{~m}$ along the drifts. At the time of sampling, streams of effluent with temperatures of 38 to $48^{\circ} \mathrm{C}$ and $\mathrm{pH}$ values near 1 flowed from drifts $\mathrm{A}, \mathrm{B}$ and $\mathrm{C}$, and the average temperature of the air in the mine was 28 to $38^{\circ} \mathrm{C}$. These warm temperatures promote evaporation of mine water, and the extreme acidity and high concentrations of metals and sulfate in the waters lead to the abundant precipitation of efflorescent minerals (Nordstrom \& Alpers 1999a). Efflorescences, stalactites, and stalagmites composed of sulfate minerals (Table 1) coat the walls, timbers and concrete supports of the mine passages, creating a colorful array of blue, green, yellow, orange, pink, and white coatings.
At the time of sampling in the D drift, water was dripping from cracks and stalactites in the walls and ceiling. Approximately 10 meters from the five-way intersection (Fig. 1), a section of the west wall of pyrite 1.0 to 1.5 meters high and 3 to 4 meters long was found to be coated in a yellow mud consisting dominantly of jarosite-group minerals (Fig. 2). The sampling area was close to the contact between the massive sulfide orebody and the host rock, a hydrothermally altered felsic volcanic rock. Water dripping from a series of dull yellow stalactites (Fig. 3) was collected, as were the stalactites and mud composed of jarosite-group minerals, as described below.

\section{Water samples}

Six beakers were placed beneath stalactites that were actively dripping yellow-orange-colored water and left overnight (98CA105A, B, D-G; Fig. 4). Sixteen hours later, the $\mathrm{pH}$, Eh, temperature and specific conductance of the sampled drip-waters were measured in the mine.

Two $50 \mathrm{~mL}$ centrifuge tubes, each containing approximately $40 \mathrm{~mL}$ of yellow, mustard-like jarositegroup minerals sampled from the stope wall, were spun on site in a small portable centrifuge for 20 minutes (water sample 98CA106). Measurements of $\mathrm{pH}$, temperature, Eh, and specific conductance were obtained from placing the probes into the residual, moist solid material.

Two pH electrodes were prepared for field measurements. They had been soaked in a sulfuric acid solution of $\mathrm{pH} 1.0$ for 23 hours to condition them before the underground sampling began. The electrodes were calibrated with a series of standard sulfuric acid solutions (Nordstrom et al. 2000) that were bathed in a pool of mine water to maintain a temperature close to that of the drip and pore waters. Millivolt readings from each of the two $\mathrm{pH}$ electrodes were converted to $\mathrm{pH}$ using regression curves for values measured from

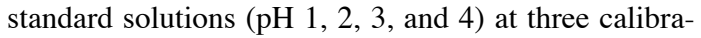
tion temperatures $\left(28,29\right.$, and $\left.45^{\circ} \mathrm{C}\right)$. In the case of the stalactite drip-waters, the $29^{\circ} \mathrm{C}$ curve was used. The most accurate electrode measurement was identified by examining the difference between the measured specific conductance and the value calculated using WATEQ4F (Ball et al. 1987).

The Eh standards consisted of $\mathrm{pH} 4$ and 7 buffer solutions to which hydroquinone was added (Makita \& Fujii 1992). Although the temperature dependence of the hydroquinone redox buffers is unknown, the temperature range encountered in this study is small, and the errors introduced are likely insignificant. The redox buffers were bathed in mine water along with the $\mathrm{pH}$ standards to ensure equilibration of temperature.

The drip waters were found to vary in color between dark and very light orange (Fig. 4). The lighter colors were found to correspond to waters with lower measured 


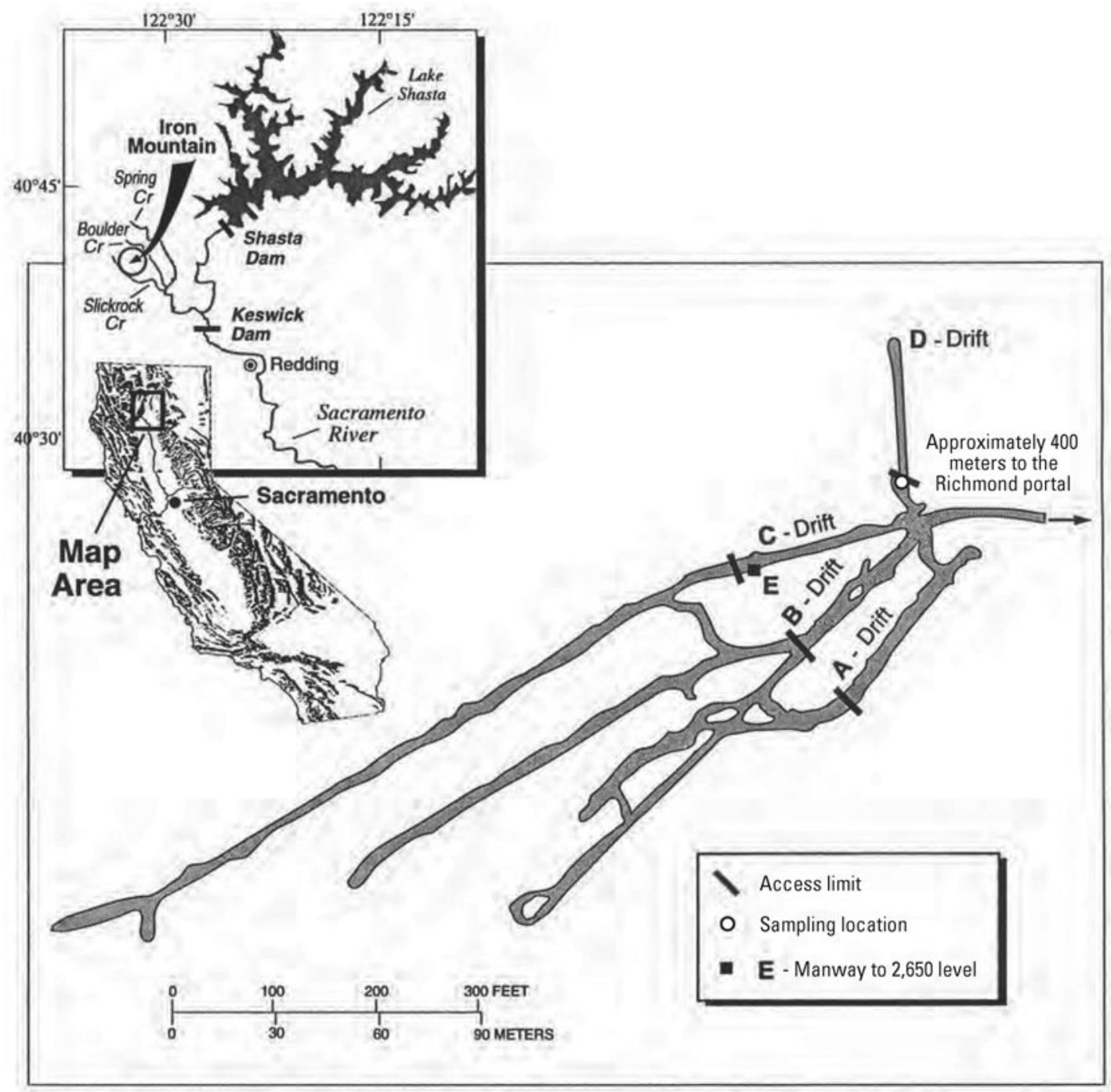

FIG. 1. Location and plan map of the underground workings, 2,600 level, Richmond mine, Iron Mountain, California.

values of Eh, whereas the darker waters exhibited higher Eh values (Table 2). We observed that the stalactites forming the drips with the lighter-orange-colored water had more bacterial slime coating the stalactite tips. The darker water seemed to be originating from "slime-free" stalactites.

\section{Mineral samples}

After the water samples had been collected, three stalactites were broken off the wall by hand and placed in centrifuge tubes to protect them from further breakage (98CR14a, b, and c).The samples of stalactite composed of jarosite-group minerals are relatively hard, opaque and a dull orange-yellow color (Munsell 2.5Y 6-7/7-8, Munsell Color Company, 1954). They range in length from 1 to $20 \mathrm{~cm}$ and in diameter from $<1$ to 3 $\mathrm{cm}$. Most samples have a hollow core that at one time accommodated water flow. In cross-section, this central cavity is surrounded by variably hued concentric bands that are apparently growth rings.

Samples 98CR15a and b were collected from the muddy part of the wall, located 2 to 3 meters from the stalactites, closer to the five-way junction (Fig. 1). They are yellow (Munsell 2.5Y 7/6) and have a smooth consistency similar to prepared mustard. 


\section{AnALYTiCAl Methods}

The waters were filtered $(0.45 \mu \mathrm{m}$ pore-diameter membrane) on site and $2.0 \mathrm{~mL}$ of concentrated $\mathrm{HNO}_{3}$ was added to the $250 \mathrm{~mL}$ fraction of each sample reserved for cation analysis and $2.0 \mathrm{~mL}$ of concentrated $\mathrm{HCl}$ to that reserved for $\mathrm{Fe}$ speciation. The level of concentration of all cations was established using inductively couple plasma - optical emission spectroscopy (ICP-OES) except $\mathrm{Na}, \mathrm{K}$, and $\mathrm{Li}$, which were done by flameless atomic absorption spectroscopy. Anions were determined using ion chromatography. The FerroZine method (Stookey 1970, To et al. 1999) was used to analyze for total $\mathrm{Fe}$ and $\mathrm{Fe}^{2+}$.

The minerals were initially identified using X-ray powder-diffraction analysis. The jarosite-group-mineral mud was dried in air, and both mud and stalactite samples were crushed gently to a powder and mounted with petroleum jelly on a glass slide. A Siemens powder diffractometer with nickel-filtered $\mathrm{CuK \alpha}$ radiation $(\lambda$ $=1.5418 \AA$ ) was used at Queen's University. Samples were scanned from $6^{\circ}$ to $60^{\circ} 2 \theta$, with a $0.1^{\circ}$ step and a 6 second preset time. The measured patterns were then matched by computer with ICDD (Joint Committee on Powder Diffraction Standards 1997) files to characterize the sample. A Gandolfi camera $(\mathrm{CoK} \alpha, 24$-hour exposure) was used to confirm the identity of the iron oxyhydroxide mineral(s) intergrown with the jarositegroup minerals.

Scanning electron imaging of stalactite fragments and air-dried mud was accomplished using a Philips XL30 CP SEM at the Royal Military College of Canada in Kingston. Polished thin sections of stalactite and mud samples were made by impregnating subsamples with an epoxy that cured at room temperature, then polishing without water. Standard analytical conditions for electron-microprobe analyses done at Queen's University in quantitative EDS mode included an accelerating voltage of $15 \mathrm{kV}$, a take-off angle of $52.5^{\circ}$, and an emission current of $100 \mathrm{~mA}$. Optimal operating conditions for analyzing jarosite-group minerals were determined by testing the effect of beam size, collection time, and beam current on a homogeneous alunite standard of known composition, no jarosite standard being available. A rastered beam with a beam current of $40 \mathrm{nA}$ and a collection time of 50 seconds was found to produce consistently accurate results, whereas longer collectiontimes and a smaller beam-spot resulted in lower values for $\mathrm{K}$ and $\mathrm{Na}$, presumably owing to the remobilization of K and Na during EMPA analysis (Hunt \& Hill 1993, Hunt et al. 1998). Primary analytical standards included synthetic chalcopyrite for $\mathrm{Fe}$, barite for $\mathrm{S}$, orthoclase for $\mathrm{K}$, kaersutitic amphibole for Na (Smithsonian USNM 143965), and a synthetic glass for $\mathrm{Al}, \mathrm{Mg}, \mathrm{Ca}$, and $\mathrm{Si}$ (U.S. National Bureau of Standards 470). Alunite from Marysville, Utah (Stoffregen \& Alpers 1987) served as a secondary analytical standard for potassium, aluminum, and sulfur; it was analyzed as an unknown periodically to ensure consistent results (Robinson 2000). All primary standards were rechecked at the end of the session. Analytical spectra were processed by fitting the reference spectra using a least-squares program to obtain uncorrected k-ratios. The k-ratios were then corrected for atomic number $(\mathrm{Z})$, absorption (A), and fluorescence (F) by the ZAF program (Doyle \& Chambers 1981). Measured concentrations of Fe, Al, and $\mathrm{S}$ in the alunite standard and a pyrite grain were consistently within $1 \mathrm{wt} \%$ (absolute) of the published or stoichiometric values, and values of the molar ratios $\mathrm{Al}: \mathrm{S}$ in alunite and $\mathrm{Fe}: \mathrm{S}$ in pyrite were found to be close to ideal. One stalactite from this study was analyzed by EMPA at the U.S. Geological Survey laboratory in Denver, Colorado using a wavelength-dispersion spectrometer (WDS) with an accelerating voltage of $10 \mathrm{kV}$, a beam current of $10 \mathrm{nA}$, and a 20 -second count time on element peaks. No migration of $\mathrm{Na}$ or $\mathrm{K}$ was observed under these conditions.

Concentrations of trace elements, including Ag, As, $\mathrm{Cd}, \mathrm{Cu}, \mathrm{Fe}, \mathrm{Ga}, \mathrm{Ge}, \mathrm{In}, \mathrm{Mo}, \mathrm{Nb}, \mathrm{Ni}, \mathrm{Pb}, \mathrm{Rb}, \mathrm{Sb}, \mathrm{Se}$, $\mathrm{Sn}, \mathrm{Sr}, \mathrm{Tl}, \mathrm{W}, \mathrm{Y}$ and $\mathrm{Zn}$, were measured using protoninduced X-ray emission (micro-PIXE) analysis at the University of Guelph, Ontario, on the same polished thin sections as were used for EMPA at Queen's University. A reduced beam-current of $1.4 \mathrm{nA}$ was applied to avoid penetration into underlying material. The reduced current lengthened the duration of analysis to approximately 700 seconds as the stopping time corresponds to charge accumulation $(1 \mu \mathrm{C})$. An Al-mylar filter (250 $\mu \mathrm{m}$ thick) in combination with a mylar filter $(125 \mu \mathrm{m}$ thick) were used to stop the back-scattered protons and to reduce the intensity and number of X-ray photons with lower energy and longer wavelength. A PIXE analysis is conventionally used as a standardless technique, and correction factors are calculated directly from an understanding of how the proton beam interacts with the sample (Cabri \& Campbell 1998). However, in this case, we were able to measure the concentration of Fe by both EMPA and micro-PIXE. In the case of the stalactites, the average concentration of iron determined by micro-PIXE corresponds very closely to that

TABLE 2. FIELD PARAMETERS OF RICHMOND MINE WATERS, JULY 1998

\begin{tabular}{|c|c|c|c|c|c|}
\hline Sample & Location & $\begin{array}{c}\text { Temperature } \\
{ }^{\circ} \mathrm{C}\end{array}$ & $\begin{array}{c}\mathrm{pH} \\
\text { Ross } \\
98-4\end{array}$ & $\begin{array}{l}\text { Eh } \\
\mathrm{mV}\end{array}$ & $\begin{array}{l}\text { S.C. } \\
\mu \mathrm{S} / \\
\mathrm{cm}\end{array}$ \\
\hline 98CA105A & Stalactite drip & 29.5 & 2.09 & 751 & 7000 \\
\hline $98 \mathrm{CA} 105 \mathrm{~B}$ & Stalactite drip & 28.9 & 2.10 & 694 & 7300 \\
\hline $98 \mathrm{CA} 105 \mathrm{D}$ & Stalactite drip & 29.3 & 2.22 & 841 & 5300 \\
\hline $98 \mathrm{CA} 105 \mathrm{E}$ & Stalactite drip & 29.4 & 2.24 & 870 & 5300 \\
\hline $98 \mathrm{CA} 105 \mathrm{~F}$ & Stalactite drip & 29.1 & 2.29 & 784 & 5000 \\
\hline $98 \mathrm{CA} 105 \mathrm{G}$ & Stalactite drip & 28.6 & 2.35 & 680 & 5300 \\
\hline $98 \mathrm{CA} 106$ & $\begin{array}{l}\text { Pore water from } \\
\text { jarosite mud }\end{array}$ & 20.0 & 1.27 & 758 & 31000 \\
\hline
\end{tabular}

S.C.: Specific conductance 


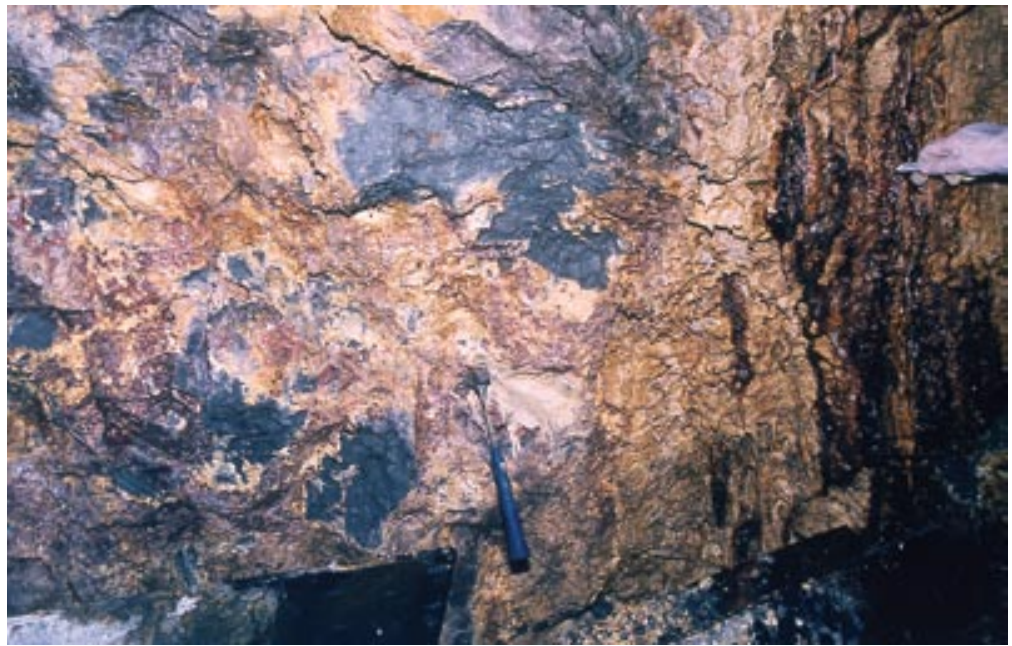

FIG. 2. Wall of jarosite-group minerals formed on the surface of massive pyrite in the D drift of the Richmond mine. On the right of the muddy section are stalactites, a redbrown mineral (goethite) and bacterial slime.

determined by EMPA (micro-PIXE results were $1 \%$ lower). This agreement demonstrates that the beam did not penetrate any underlying Fe oxyhydroxides, the only other minerals present in significant quantities in the section. The concentration of Fe determined by micro-PIXE in the mud sample is approximately $10 \%$ lower than that determined by EMPA, probably owing to the smaller crystals of the jarosite-group-mineral in the mud relative to those in the stalactite, and the microPIXE data were refit by using the Fe value determined by EMPA. The results were evaluated independently in each analysis by ensuring an acceptable fit-error and limit of detection (LOD). Concentrations greater than three times the LOD were considered significant. In addition, the spectra for each analysis were examined for residual peaks. The elements present in the samples of the jarosite-group-mineral in significant concentration, according to these criteria, are discussed below.

\section{RESULTS}

\section{Composition of water}

The composition of the six samples of drip water collected from stalactites and of one sample of pore water extracted from the mud is listed in Table 3. These compositions are similar to that of other acid-mine-drainage water from the Richmond mine in that the dominant dissolved species are $\mathrm{Fe}^{3+}$ and $\mathrm{SO}_{4}{ }^{2-}$ (Nordstrom \& Alpers 1999a, b, Nordstrom et al. 2000, Jamieson et al. 2005). However, they are considerably more dilute and less acidic than most other drainage waters from the Richmond mine. For example, the dissolved sulfate content of the drip waters are one to two orders of

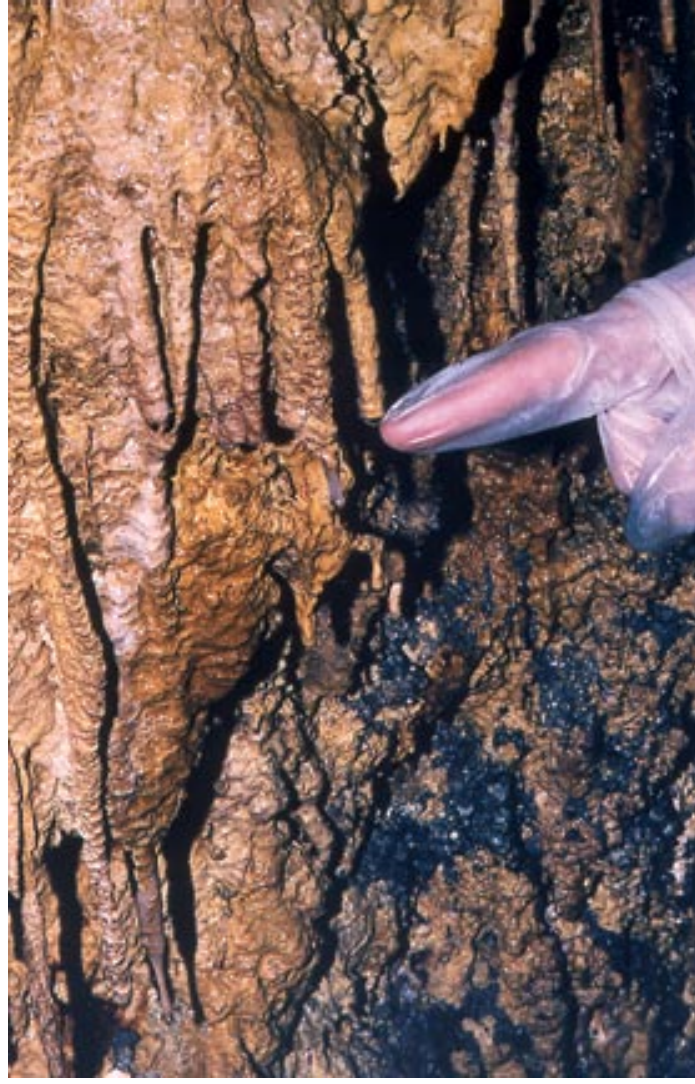

FIG. 3. Close-up view of dripping stalactite consisting of jarosite-group minerals. 


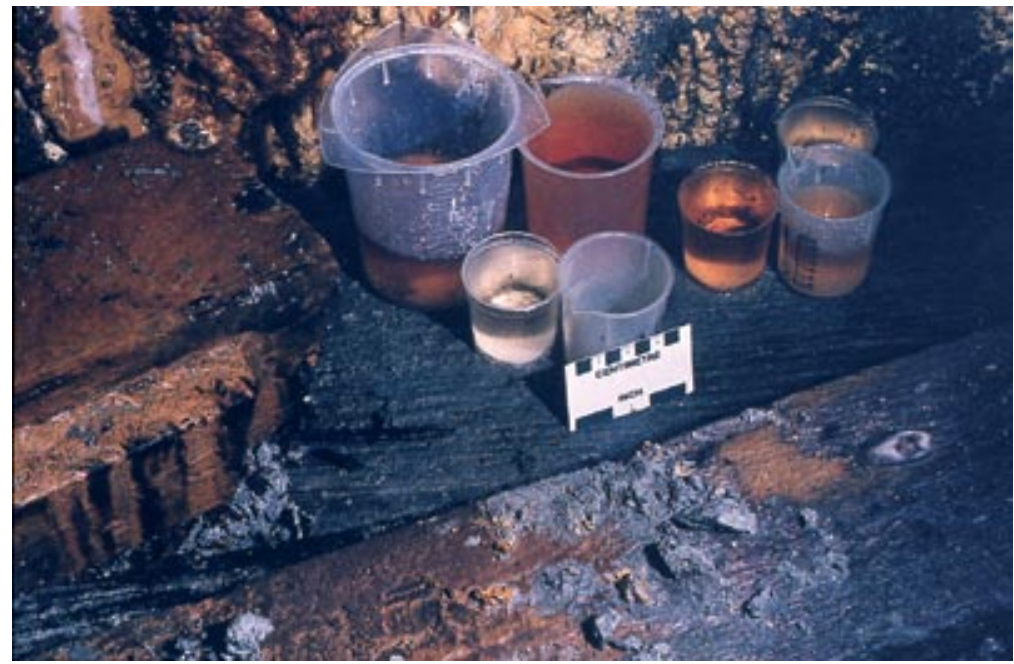

FIG. 4. Stalactite drip waters collected overnight. From left to right, beginning with the largest beaker: 105A, 105D, 105E, 105F. Sample 105G is behind 105F. In front, 105B and $105 \mathrm{C}$, which is empty.

TABLE 3. COMPOSITION OF WATER DRIPPING FROM JAROSITE STALACTITES (98CA 105 SERIES) AND EXTRACTED FROM JAROSITE MUD (98CAI06)

\begin{tabular}{|c|c|c|c|c|c|c|c|}
\hline Sample & $\begin{array}{l}98 \mathrm{CA} \\
105 \mathrm{~A}\end{array}$ & $\begin{array}{c}98 \mathrm{CA} \\
105 \mathrm{~B}\end{array}$ & $\begin{array}{c}98 \mathrm{CA} \\
105 \mathrm{D}\end{array}$ & $\begin{array}{c}98 \mathrm{CA} \\
105 \mathrm{E}\end{array}$ & $\begin{array}{c}98 \mathrm{CA} \\
105 \mathrm{~F}\end{array}$ & $\begin{array}{l}98 \mathrm{CA} \\
105 \mathrm{G}\end{array}$ & $\begin{array}{r}98 \mathrm{CA} \\
106\end{array}$ \\
\hline density $\mathrm{g} / \mathrm{mL}$ & 1.0050 & 1.0038 & 1.0038 & 1.0057 & 1.0035 & 1.0015 & $5 \quad 0.9991$ \\
\hline Ca mg/L & 184 & 159 & 162 & 168 & 168 & 154 & 268 \\
\hline $\mathrm{Mg}$ & 65.2 & 58.9 & 56.0 & 57.4 & 64.8 & 64.3 & 107 \\
\hline $\mathrm{Na}$ & 17.5 & 17.2 & 15.5 & 15.3 & 15.3 & 20.6 & 24.6 \\
\hline $\mathrm{K}$ & 0.716 & 1.82 & 0.341 & 0.402 & 0.093 & 8.65 & 2.31 \\
\hline $\mathrm{Li}$ & 0.048 & 0.042 & 0.039 & 0.041 & 0.049 & 0.55 & 0.016 \\
\hline $\mathrm{SiO}_{2}$ & 139 & 131 & 123 & 1.26 & 137 & 129 & 192 \\
\hline Al & 83.1 & 76.3 & 85.9 & 81.4 & 88.9 & 87.6 & 115 \\
\hline $\mathrm{Fe}_{\mathrm{T} t \mathrm{tal}} *$ & 1.53 & 1.16 & 1.16 & 1.09 & 0.957 & 0.934 & 7.92 \\
\hline $\mathrm{Fe}^{2 * *}$ & 0.097 & 0.570 & 0.001 & 0.004 & 0.008 & 0.378 & 0.988 \\
\hline $\mathrm{Mn}$ & 4.18 & 2.98 & 3.42 & 3.19 & 2.68 & 2.09 & 10.1 \\
\hline B & $<0.04$ & $<0.04$ & $<0.04$ & $<0.04$ & $<0.04$ & $<0.04$ & $<1.4$ \\
\hline St & 0.001 & 0.009 & $<0.001$ & $<0.001$ & $<0.001$ & 0.011 & $<0.04$ \\
\hline $\mathrm{Ba}$ & $<0.007$ & $<0.007$ & $<0.007$ & $<0.007$ & $<0.007$ & $<0.007$ & $<0.28$ \\
\hline $\mathrm{Cu}$ & 0.624 & 0.378 & 0.328 & 0.259 & 0.173 & $<0.08$ & 36.9 \\
\hline $\mathrm{Zn}$ & 37.4 & 26.6 & 31.9 & 30.0 & 26.5 & 23.6 & 195 \\
\hline $\mathrm{Cd}$ & 0.170 & 0.116 & 0.091 & 0.098 & 0.101 & $0.10 !$ & 0.942 \\
\hline $\mathrm{Co}$ & 0.308 & 0.196 & 0.174 & 0.133 & 0.042 & 0.014 & 5.51 \\
\hline $\mathrm{Cr}$ & 0.078 & 0.122 & 0.171 & 0.160 & 0.131 & 0.070 & $<1.8$ \\
\hline $\mathrm{Ni}$ & 0.083 & 0.035 & 0.050 & 0.046 & 0.021 & 0.013 & 0.282 \\
\hline $\mathrm{Pb}$ & $<0.05$ & $<0.05$ & $<0.05$ & $<0.05$ & $<0.05$ & $<0.05$ & $<0.2$ \\
\hline V & 0.218 & 0.182 & 0.162 & 0.132 & 0.092 & 0.145 & $<0.2$ \\
\hline$A s_{\text {Toli: } 1}$ & 1.77 & 1.21 & 1.31 & 1.26 & 0.991 & 1.02 & 13.3 \\
\hline $\mathrm{As}^{3 .+1}$ & 0.163 & 0.129 & 0.139 & 0.131 & 0.095 & 0.104 & $<0.0005$ \\
\hline $\mathrm{Be}$ & $<0.001$ & $<0.001$ & $<0.001$ & $<0.001$ & $<0.001$ & $<0.00 \mathrm{I}$ & $<0.001$ \\
\hline $\mathrm{Ti}$ & 0.027 & 0.011 & 0.017 & 0.013 & 0.006 & 0.003 & $<0.07$ \\
\hline $\mathrm{SO}_{4}$ & 6200 & 4770 & 4820 & 4840 & 4600 & 3690 & 32900 \\
\hline F & 2.06 & 1.73 & 2.14 & 2.29 & 2.08 & 1.86 & 8.96 \\
\hline Cl & 11.8 & 9.26 & 10.1 & 14.7 & 8.93 & 8.18 & 89.1 \\
\hline $\mathrm{Br}$ & $<1$ & $<1$ & $<1$ & $<1$ & $<1$ & $<1$ & $<4$ \\
\hline $\mathrm{NO}_{3}$ & 2.79 & 3.01 & 2.67 & 2.95 & 3.26 & 3.01 & 21.4 \\
\hline
\end{tabular}

* $g / L$ magnitude less than that measured in other Richmond mine waters, including pore water from an accumulation of copiapite-group minerals found a few meters away from the sampling site of the jarosite-group mineral, in the D drift (Nordstrom et al. 2000, Jamieson et al. 2005). The pore water from jarositic mud (sample 98CA106) contains approximately ten times as much dissolved iron and sulfate as the drip waters, but it is still relatively dilute compared to other waters from the mine. The dissolved $\mathrm{Fe}$ is dominantly $\mathrm{Fe}^{2+}$, whereas in the case of the drip waters, it is mostly $\mathrm{Fe}^{3+}$, though the $\mathrm{Fe}^{2+}: \mathrm{Fe}^{3+}$ ratio varies from 0.001 to 0.966 (Table 3). Concentrations of $\mathrm{Zn}, \mathrm{Cu}, \mathrm{Cd}, \mathrm{Pb}$ and $\mathrm{As}$ in all samples listed in Table 3 are much lower than values measured in other water samples from Richmond mine, especially drip waters associated with other iron minerals (Nordstrom \& Alpers 1999a). The measured values of $\mathrm{pH}$ for the water coexisting with the samples of jarosite-group mineral are between 1.3 and 2.3 (Table 2), whereas those of previously reported waters from the Richmond mine are between -3.6 and 1.5 (Nordstrom et al. 2000, Alpers et al. 2003). The waters in Table 3 are more similar to acid mine-waters reported from other sites and less like the extremely acidic, metal- and sulfaterich drainage observed elsewhere in the Iron Mountain system. A possible explanation for the more dilute nature of these waters in the D drift is that this area is near the edge of the massive sulfide, where percolating waters have more opportunity to interact with the hydrothermally altered metavolcanic host-rocks.

The six samples of stalactite drip-waters are similar in composition to each other with the exception of their 
$\mathrm{Fe}^{3+}: \mathrm{Fe}^{2+}$ ratio (Table 3). There is a direct correspondence between color, measured $\mathrm{Eh}$, and $\mathrm{Fe}^{3+}$, such that the darkest orange waters have the highest $\mathrm{Fe}^{3+}$ content, $\mathrm{Fe}^{3+}: \mathrm{Fe}^{2+}$ ratio, and measured $\mathrm{Eh}$. The simple relationship between water color and redox state cannot be extrapolated to other Richmond mine waters, however, as more reduced waters with higher $\mathrm{Fe}^{2+}$ and sulfate concentrations can be blue-green, and waters of similar measured Eh values to these drip waters but of lower $\mathrm{pH}$ can be dark brown (Robinson 2000), probably caused by higher concentrations of $\mathrm{Fe}^{3+}$ and sulfate. Although the composition of the water extracted from the jarositic mud is somewhat different than that of the drip waters, field relations indicate that both types of water are closely associated with jarosite-group minerals that are actively forming. As discussed below, geochemical modeling was used to test the hypothesis that these water compositions are close to thermodynamic equilibrium with the associated jarosite-group minerals.

\section{Composition of the jarosite-group minerals}

The SEM images of stalactite fragments show rhombohedral crystals no larger than $10 \mu \mathrm{m}$ in diameter (Fig. 5a). Many grains are partially encrusted with finergrained light-colored silica, identified by EDS. Crystals of jarosite-group minerals from the mud sample appear to be slightly smaller $(<8 \mu \mathrm{m})$ and exhibit little or no encrustation with silica (Fig. 5b).
In thin section, samples of the jarosite-group mineral appear in transmitted light as rounded, yellow-orange blebs less than $40 \mu \mathrm{m}$ in diameter, which represent spheroidal aggregates of the tiny rhombohedral crystals seen in the SEM images. In some areas, a red-brown mineral with internal reflections in reflected light is probably goethite. A Gandolfi camera was used to obtain a diffraction pattern of a small amount of the red-brown mineral scraped from a thin section. The resulting pattern is complicated by the presence of a jarosite-group mineral, but includes the most intense peak of goethite (JCPDS 1997).

The X-ray powder-diffraction patterns of samples of the jarosite-group minerals indicate a close match with jarosite as well as distinctive shoulders on several peaks at $d$ values corresponding to hydronium-bearing jarosite and hydronium jarosite (Stoffregen et al. 2000). This was observed in both the XRD data collected at Queen's University on stalactite and mud samples, and those collected at the U.S. Geological Survey, Denver Laboratory, on a stalactite sample. The results indicate a physical mixture of jarosite and hydronium jarosite, with jarosite being the more abundant.

Representative results of EMPA of the jarosite-group minerals present as stalactites, and all the compositions of the mud, are listed in Table 4. The calculated structural formulae are listed in Table 4 and plotted in Figure 6 . The relatively low $\mathrm{K}$ and very low $\mathrm{Na}$ are considered to be caused by the presence of $\mathrm{H}_{3} \mathrm{O}$ at the

TABLE 4A . RESULTS OF ELECTRON-MICROPROBE ANALYSES OF SAMPLES OF JAROSITE-GROUP MINERALS

\begin{tabular}{|c|c|c|c|c|c|c|c|c|c|c|c|c|c|}
\hline & 1 & 2 & 3 & 4 & 5 & 6 & 7 & 8 & 36 & 38 & 41 & 42 & 43 \\
\hline $\mathrm{Al}_{2} \mathrm{O}_{3}$ wt. $\%$ & 60.38 & 0.11 & 0.26 & 0.40 & 0.19 & 0.49 & 0.49 & n.d. & 0.32 & 0.26 & 0.26 & 0.30 & 0.42 \\
\hline $\mathrm{Fe}_{2} \mathrm{O}_{3}$ & 43.87 & 42.21 & 43.83 & 42.93 & 44.24 & 43.17 & 44.72 & 42.17 & 43.40 & 46.70 & 42.47 & 42.99 & 42.80 \\
\hline $\mathrm{MgO}$ & n.d. & 1.16 & n.d. & n.d. & 0.20 & n.d. & n.d. & 0.17 & n.d. & n.d. & n.d. & n.d. & n.d. \\
\hline $\mathrm{CaO}$ & 0.24 & 0.27 & 0.14 & 0.21 & 0.10 & n.d. & n.d. & n.d. & n.d. & 0.11 & 0.15 & n.d. & 0.13 \\
\hline $\mathrm{Na}_{2} \mathrm{O}$ & n.d. & 0.22 & n.d. & n.d. & 0.78 & 0.70 & 0.66 & 0.34 & 0.80 & n.d. & n.d. & n.d. & 0.22 \\
\hline $\mathrm{K}_{\uparrow} \mathrm{O}$ & 8.00 & 6.52 & 8.25 & 6.43 & 3.37 & 3.35 & 3.67 & 5.82 & 2.46 & 5.43 & 7.75 & 7.87 & 7.72 \\
\hline $\mathrm{SO}_{3}$ & 31.19 & 33.96 & 33.19 & 34.48 & 33.51 & 32.69 & 33.39 & 32.56 & 31.96 & 32.64 & 31.29 & 30.56 & 32.94 \\
\hline $\mathrm{H}_{2} \mathrm{O}$ & 11.20 & 13.26 & 12.07 & 13.77 & 14.35 & 14.02 & 14.22 & 12.85 & 14.07 & 13.41 & 11.39 & 10.96 & 12.06 \\
\hline Total & 94.88 & 96.71 & 97.74 & 98.22 & 96.74 & 94.42 & 97.15 & 93.91 & 93.01 & 98.55 & 93.31 & 92.68 & 96.29 \\
\hline $\mathrm{Al}$ apfu & 0.04 & 0.01 & 0.02 & 0.04 & 0.02 & 0.05 & 0.05 & 0.00 & 0.03 & 0.03 & 0.03 & 0.03 & 0.04 \\
\hline $\mathrm{Fe}^{3:}$ & 2.82 & 2.49 & 2.65 & 2.50 & 2.65 & 2.65 & 2.69 & 2.60 & 2.72 & 2.87 & 2.72 & 2.82 & 2.61 \\
\hline $\mathrm{Mg}$ & 0.00 & 0.00 & 0.00 & 0.00 & 0.00 & 0.00 & 0.00 & 0.00 & 0.00 & 0.00 & 0.00 & 0.00 & 0.00 \\
\hline $\mathrm{Ca}$ & 0.00 & 0.00 & 0.00 & 0.00 & 0.00 & 0.00 & 0.00 & 0.00 & 0.00 & 0.00 & 0.00 & 0.00 & 0.00 \\
\hline $\mathrm{Na}$ & 0.00 & 0.03 & 0.00 & 0.00 & 0.12 & 0.11 & 0.10 & 0.05 & 0.13 & 0.00 & 0.00 & 0.00 & 0.03 \\
\hline $\mathrm{K}$ & 0.87 & 0.65 & 0.85 & 0.63 & 0.34 & 0.35 & 0.37 & 0.61 & 0.26 & 0.57 & 0.84 & 0.88 & 0.80 \\
\hline $\mathrm{H}_{3} \mathrm{O}^{\circ}$ & 0.13 & 0.31 & 0.15 & 0.37 & 0.54 & 0.54 & 0.52 & 0.34 & 0.61 & 0.43 & 0.16 & 0.12 & 0.17 \\
\hline $\mathrm{S}$ & 2 & 2 & 2 & 2 & 2 & 2 & 2 & 2 & 2 & 2 & 2 & 2 & 2 \\
\hline $\mathrm{O}$ & 8 & 8 & 8 & 8 & 8 & 8 & 8 & 8 & 8 & 8 & 8 & 8 & 8 \\
\hline $\mathrm{OH}$ & 5.58 & 4.51 & 5.02 & 4.60 & 5.00 & 5.09 & 5.20 & 4.79 & 5.26 & 5.68 & 5.24 & 5.56 & 4.94 \\
\hline $\mathrm{H}_{2} \mathrm{O}$ & 0.21 & 0.75 & 0.49 & 0.70 & 0.50 & 0.46 & 0.40 & 0.60 & 0.37 & 0.16 & 0.38 & 0.22 & 0.53 \\
\hline
\end{tabular}

Compositions determined at Queen's University. Compositions 1-8 pertain to stalactites, the remainder to mud samples. n.d.: not detected. $\mathrm{H}_{2} \mathrm{O}$ refers to concentrations calculated by difference and charge balance in stoichiometry. The $\mathrm{H}_{3} \mathrm{O}^{+}$in the formulae is calculated by difference at the alkali site. $\mathrm{The}_{2} \mathrm{O}$ in the formulae is calculated by protonation of $\mathrm{OH}$ to achieve charge balance. $\mathrm{Ca}$ and $\mathrm{Mg}$ not included in formulae. 
alkali site. The $\mathrm{H}_{3} \mathrm{O}$ content was calculated by difference, and the $\mathrm{H}_{2} \mathrm{O}$ was computed. The presence of a hydronium jarosite component in the sample was also confirmed by spectral reflectance data (G. Swayze, U.S. Geological Survey, written commun., 2004). The (Fe + $\mathrm{Al}): \mathrm{S}$ molar ratio for jarosite-group minerals analyzed in this study varies from $2.50: 2$ to $2.97: 2$, which is less than the ideal ratio of $3: 2$, but well within the range reported by others for natural and synthetic materials [Härtig et al. (1984): 2.20:2 to 2.57:2, Ripmeester et al. (1986): as low as 2.33:2, Alpers et al. (1989): 2.85:2 to 2.96:2, Baron \& Palmer (1996): 2.79:2, Drouet \& Navrotsky (2003): 2.48 to $2.91: 2$, Paktunc \& Dutrizac (2003): $2.54: 2$ to $2.88: 2]$.

The most striking aspect of the compositions of the jarosite-group minerals analyzed in this study is the very

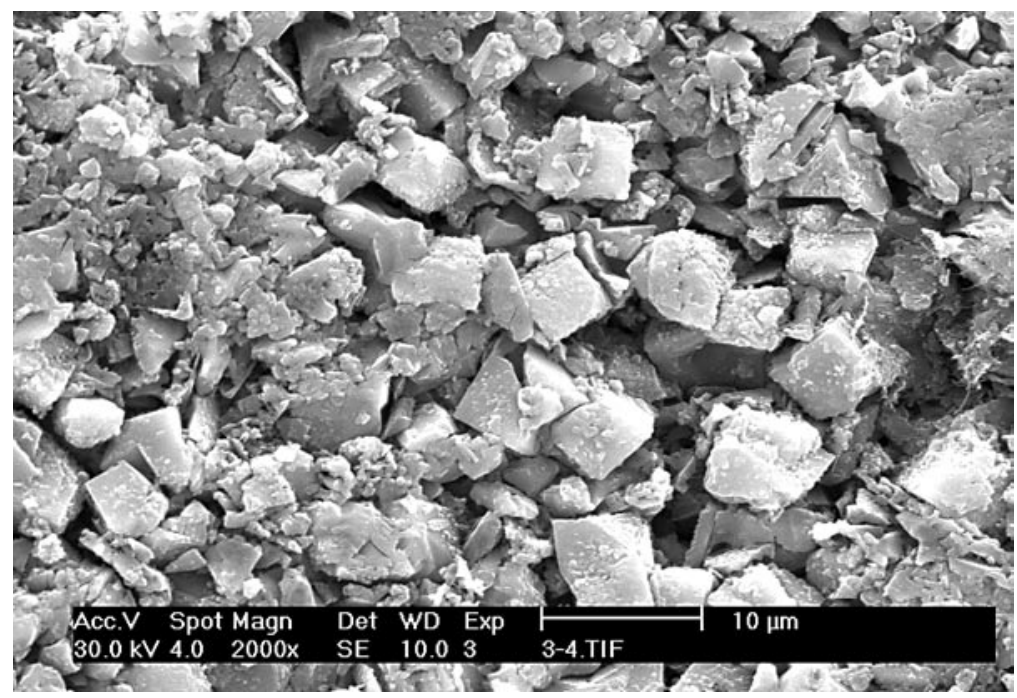

FIG. 5a. SEM image of the stalactite of jarosite-group mineral. The crystals are coated by fine-grained amorphous silica.

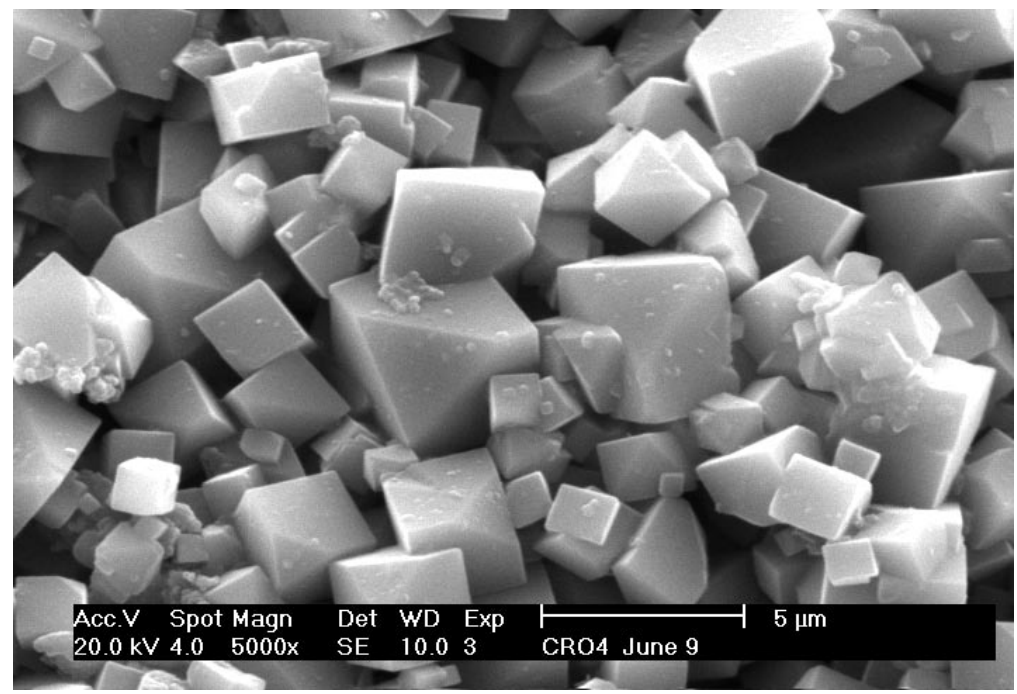

FIG. 5b. SEM image of jarosite-group mineral in the mud sample. Silica coating is essentially absent. 
TABLE 4B . RESULTS OF ELECTRON-MICROPROBE ANALYSES OF SAMPLES OF JAROSITE-GROUP MINERALS

\begin{tabular}{|c|c|c|c|c|c|c|c|c|c|c|c|c|c|}
\hline & 27 & 30 & 32 & 33 & 34 & 39 & 40 & 45 & 46 & 49 & 56 & 58 & 73 \\
\hline $\mathrm{Al}_{2} \mathrm{O}_{3}$ wt. $\%$ & 0.04 & n.d. & 0.04 & n.d. & 0.04 & 0.09 & 0.04 & n.d. & 0.04 & n.d. & n.d. & n.d. & n.d. \\
\hline $\mathrm{Fe}_{2} \mathrm{O}_{3}$ & 42.9 & 43.0 & 43.8 & 43.8 & 43.1 & 45.3 & 44.3 & 42.7 & 42.5 & 44.5 & 42.8 & 43.5 & 45.7 \\
\hline $\mathrm{MgO}$ & n.d. & n.d. & n.d. & n.d. & n.d. & n.d. & n.d. & n.d. & n.d. & n.d. & n.d. & n.d. & n.d. \\
\hline $\mathrm{CaO}$ & n.d. & n.d. & n.d. & n.d. & n.d. & n.d. & n.d. & n.d. & n.d. & n.d. & n.d. & n.d. & n.d. \\
\hline $\mathrm{Na}_{2} \mathrm{O}$ & 0.49 & 0.13 & 0.21 & 0.24 & 0.62 & 3.27 & 1.97 & 0.35 & 0.38 & 2.18 & 0.72 & 1.54 & 0.22 \\
\hline $\mathrm{K}_{2} \mathrm{O}$ & 5.12 & 7.00 & 6.95 & 6.28 & 5.59 & 1.34 & 3.04 & 4.98 & 5.39 & 3.89 & 5.11 & 4.10 & 4.80 \\
\hline $\mathrm{SO}_{3}$ & 32.3 & 30.8 & 30.8 & 31.1 & 32.0 & 31.8 & 30.6 & 32.2 & 31.0 & 31.0 & 30.9 & 31.0 & 32.5 \\
\hline $\mathrm{H}_{2} \mathrm{O}$ & 12.99 & 11.46 & 11.42 & 11.93 & 12.45 & 12.48 & 12.03 & 13.14 & 12.27 & 11.56 & 12.08 & 12.00 & 13.51 \\
\hline Total & 93.84 & 92.39 & 93.22 & 93.35 & 93.80 & 94.28 & 91.98 & 93.37 & 91.58 & 93.13 & 91.61 & 92.14 & 96.73 \\
\hline $\mathrm{Al}$ apfu & 0.00 & 0.00 & 0.00 & 0.00 & 0.00 & 0.00 & 0.00 & 0.00 & 0.00 & 0.00 & 0.00 & 0.00 & 0.00 \\
\hline $\mathrm{Fe}^{3+}$ & 2.66 & 2.80 & 2.85 & 2.82 & 2.70 & 2.86 & 2.90 & 2.66 & 2.75 & 2.88 & 2.78 & $2.8]$ & 2.82 \\
\hline $\mathrm{Mg}$ & 0.00 & 0.00 & 0.00 & 0.00 & 0.00 & 0.00 & 0.00 & 0.00 & 0.00 & 0.00 & 0.00 & 0.00 & 0.00 \\
\hline $\mathrm{Ca}$ & 0.00 & 0.00 & 0.00 & 0.00 & 0.00 & 0.00 & 0.00 & 0.00 & 0.00 & 0.00 & 0.00 & 0.00 & 0.00 \\
\hline $\mathrm{Na}$ & 0.08 & 0.02 & 0.04 & 0.04 & 0.10 & 0.53 & 0.33 & 0,06 & 0.06 & 0.36 & 0.12 & 0.26 & 0.03 \\
\hline $\mathrm{K}$ & 0.54 & 0.77 & 0.77 & 0.69 & 0.50 & 0.14 & 0.34 & 0.53 & 0.59 & 0.43 & 0.56 & 0.45 & 0.50 \\
\hline $\mathrm{H}_{3} \mathrm{O}^{+}$ & 0.38 & 0.21 & 0.20 & 0.27 & $0.3 \mathrm{I}$ & 0.33 & 0.33 & 0.42 & 0.35 & 0.21 & 0.32 & 0.29 & 0.46 \\
\hline $\mathrm{S}^{-1}$ & 2 & 2 & 2 & 2 & 2 & 2 & 2 & 2 & 2 & 2 & 2 & 2 & 2 \\
\hline 0 & 8 & 8 & 8 & 8 & 8 & 8 & 8 & 8 & 8 & 8 & 8 & 8 & 8 \\
\hline $\mathrm{OH}$ & 5.00 & 5.40 & 5.57 & 5.47 & 5.12 & 5.60 & 5.72 & 4.98 & 5.26 & 5.64 & 5.33 & 5.44 & 5.46 \\
\hline $\mathrm{H}_{2} \mathrm{O}$ & 0.50 & 0.30 & 0.22 & 0.26 & 0.44 & 0.20 & 0.14 & 0.51 & 0.37 & 0.18 & 0.33 & 0.28 & 0.27 \\
\hline
\end{tabular}

\begin{abstract}
Compositions of stalactites determined at the U.S. Geological Survey in Denver. n.d.: not detected. $\mathrm{H}_{2} \mathrm{O}$ refers to concentrations calculated by difference and charge balance in stoichiometry. The $\mathrm{H}_{3} \mathrm{O}^{-}$in the formulae is calculated by difference at the alkali site. The $\mathrm{H}_{2} \mathrm{O}$ in the formulae is calculated by protonation of $\mathrm{OH}$ to achieve charge balance. $\mathrm{Ca}$ and $\mathrm{Mg}$ not included in formulae
\end{abstract}

wide range in composition with respect to the jarosite, hydronium jarosite, and natrojarosite end-members from what might initially be considered a common environment of formation (Fig. 6). This is true for both the stalactites and the mud. X-ray mapping with the electron microprobe (Fig. 7) indicates that the crystals composing the stalactites are zoned with respect to $\mathrm{Na}$ and $\mathrm{K}$ (and $\mathrm{H}_{3} \mathrm{O}$ as calculated by difference) at a scale comparable to the size of the analytical volume, suggesting that the compositions listed in Table 4 and plotted in Figure 6 represent mixtures. The variation in composition is not related to the apparent growth-rings in the stalactite. This pattern suggests that the composition of the jarosite-group mineral solid-solution in terms of the relative amounts of $\mathrm{K}, \mathrm{Na}$, and $\mathrm{H}_{3} \mathrm{O}$ is very sensitive to variation in one or more parameters in the environment of precipitation, and that this variation occurred during the formation of the stalactites and mud wall.

Given that there are several cation-sites in the jarosite-group mineral structure and that extensive substitution of some base metals into jarosite-group minerals has been documented elsewhere (e.g., Scott 1987, Dutrizac \& Jambor 2000, and references therein), it is not surprising that a variety of trace elements are sequestered within the jarosite-group minerals at the Richmond mine. Micro-PIXE analyses indicate that $\mathrm{Zn}, \mathrm{As}$ and $\mathrm{Pb}$ are present in the stalactites in significant concentrations, i.e., more than three times above the limit of detection. The results are listed in Table 5 . The fit error and LOD were calculated according to the method of Cabri \& Campbell (1998). Concentrations of $\mathrm{Rb}, \mathrm{Sr}$ and $\mathrm{Sb}$ are also present in significant but lower amounts (averaging $26 \pm 8 \mathrm{ppm}, n=15 ; 38 \pm 17 \mathrm{ppm}$, $n=18 ; 176 \pm 159 \mathrm{ppm}, n=18$, respectively). The jarosite-group minerals present in the mud do not contain significant $\mathrm{Zn}$, but the average concentrations of $\mathrm{Pb}$ $(5,961 \mathrm{ppm})$ and As $(435 \mathrm{ppm})$ are higher than those in the stalactites, and $\mathrm{Bi}, \mathrm{Se}$, and $\mathrm{Sn}$ were detected in most samples of the mud ( $207 \pm 58 \mathrm{ppm}, n=6 ; 121 \pm 75 \mathrm{ppm}$, $n=10 ; 155 \pm 40 \mathrm{ppm}, n=6$, respectively). Because it was not possible to collect micro-PIXE spectra on the same spots that were analyzed by EPMA owing to beam damage, the trace-element results cannot be correlated with the variation in $\mathrm{K}-\mathrm{Na}-\mathrm{H}_{3} \mathrm{O}$ content in the jarositegroup minerals. Lead probably substitutes for $\mathrm{K}$, on the basis of the well-known stability of plumbojarosite in oxidized portions of lead-rich sulfide deposits (Dutrizac \& Jambor 2000, Hochella et al. 2005). Bismuth and $\mathrm{Sr}$ also may occupy the $D$ site, as several Bi-bearing and Sr-bearing end-members of the crandallite group (part of the alunite supergroup) are known (Dutrizac \& Jambor 2000). Rubidium is expected to substitute for $\mathrm{K}$. Zinc is known to substitute for $\mathrm{Fe}$ in jarositegroup minerals and other hydrous Fe sulfates from Iron Mountain (Jamieson et al. 1999), and, on the basis of ionic radius and charge, $\mathrm{Sn}$ probably does as well. 


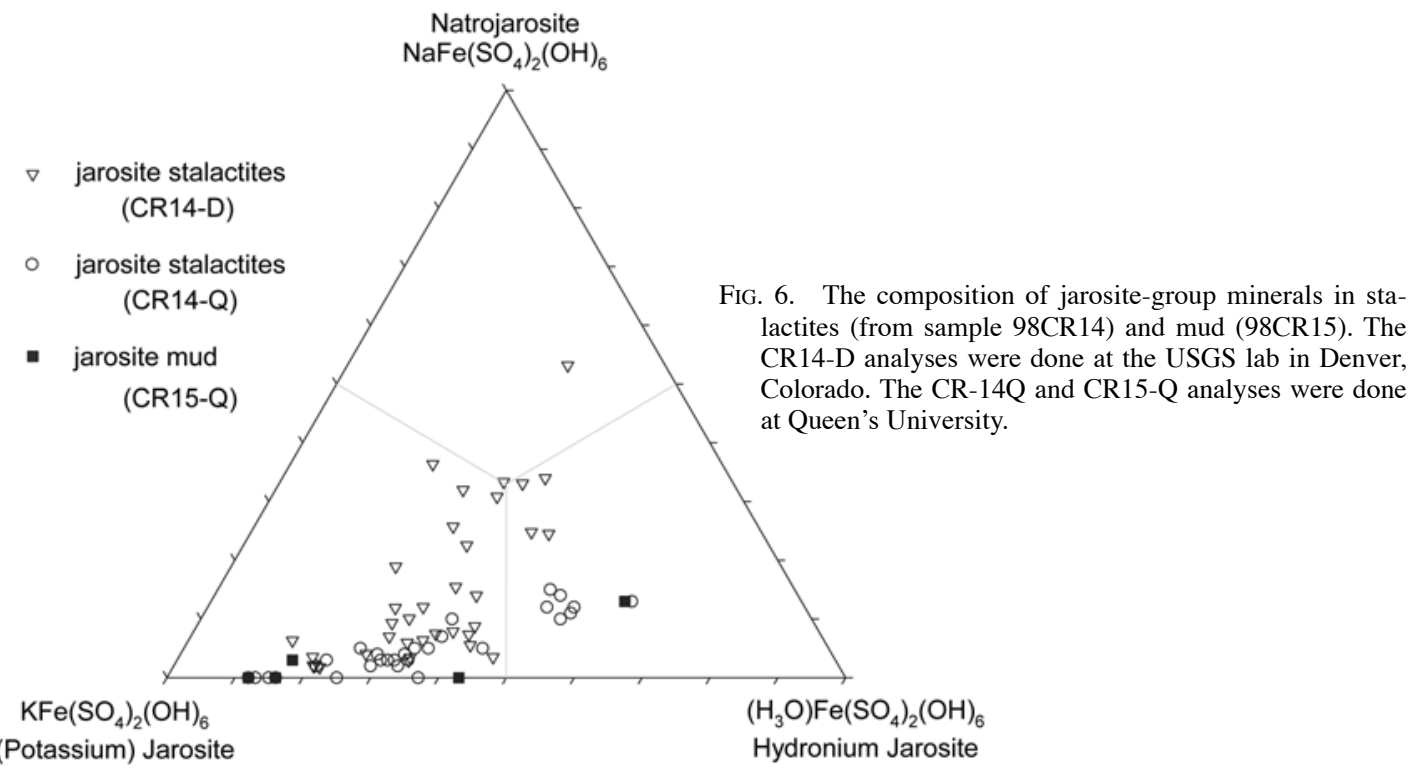

FIG. 7. X-ray intensity-distribution maps (electron-microprobe data) of crystals of the jarosite-group minerals from a stalactite. Blue shades represent less intense areas (less of the respective element) and red or orange shades represent more intense areas (more of the respective element). Note that high-K areas correspond to low-Na areas. $\mathrm{CP}$ : backscattered-electron image.

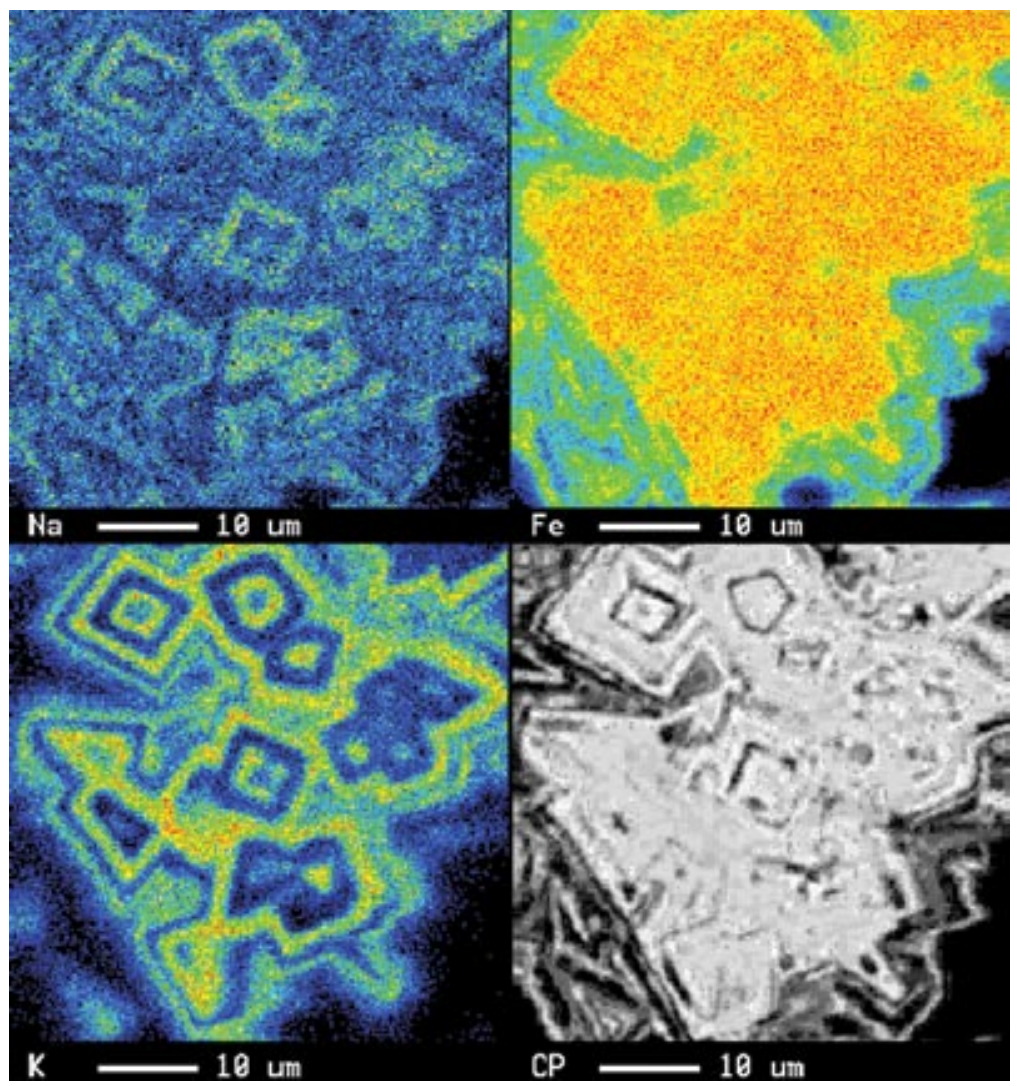


Arsenic, $\mathrm{Se}$, and $\mathrm{Sb}$ are expected to behave as $T$ ions. The substitution of $\mathrm{AsO}_{4}{ }^{3-}$ for $\mathrm{SO}_{4}{ }^{2-}$ has been reported for jarosite-group minerals (Paktunc \& Dutrizac 2003, Savage et al. 2005) and in other hydrous Fe sulfates from Iron Mountain (Jamieson et al. 1999, 2005).

\section{Other minerals}

Electron-microprobe analyses of iron oxyhydroxide minerals were difficult owing to the small grain-size and variable quality of polished surfaces. The Fe content at twenty-six points on the grains that appear, in backscattered electron imaging, to be the brightest and smoothest varies significantly (45 to $60 \mathrm{wt} \% \mathrm{Fe}$ ) and is consistent with either ferrihydrite or goethite, but is less than that expected for hematite. Most compositions include small amounts of $\mathrm{Si}$ and $\mathrm{Ca}$. Where $\mathrm{S}$ is present, the amounts are higher than that expected for schwertmannite (Bigham \& Nordstrom 2000) and probably represent admixed jarosite-group minerals. On the basis of the EMPA, XRD, and microscopic observations, the red-brown mineral has been tentatively identified as goethite. Micro-PIXE analysis of the iron oxyhydroxide grains also showed considerable grain-to-grain variation in Fe concentration and thus the trace-element analyses can only be considered semiquantitative. Zinc and As appear to be present in significant concentrations (tens to thousands of ppm).

\section{GeOchemicAl Modeling}

We used the geochemical modeling program WATEQ4F (Ball et al. 1987) to calculate aqueous

TABLE 5. LEVELS OF TRACE ELEMENTS IN SAMPLES OF JAROSITE STALACTITE

\begin{tabular}{|c|c|c|c|c|c|c|c|c|c|}
\hline & \multicolumn{3}{|c|}{$\mathrm{Zn}$} & \multicolumn{3}{|c|}{ As } & \multicolumn{3}{|c|}{$\mathrm{Pb}$} \\
\hline & $\begin{array}{l}\text { Conc } \\
\text { ppm }\end{array}$ & $\begin{array}{l}\text { Error } \\
\% \mathrm{Fit}\end{array}$ & $\begin{array}{l}\text { LOD } \\
\text { ppm }\end{array}$ & $\begin{array}{l}\text { Conc } \\
\text { ppm }\end{array}$ & $\begin{array}{l}\text { Error } \\
\% \text { Fit }\end{array}$ & $\begin{array}{l}\text { LOD } \\
\text { ppm }\end{array}$ & $\begin{array}{l}\text { Conc } \\
\text { ppm }\end{array}$ & $\begin{array}{l}\text { Error } \\
{ }_{0} \text { Fit }\end{array}$ & $\begin{array}{l}\text { LOD } \\
\text { ppm }\end{array}$ \\
\hline \multicolumn{10}{|c|}{ 98CRI4-D } \\
\hline 1 & 93 & 7 & 7 & 141 & 6 & 28 & 1234 & 2 & 49 \\
\hline 2 & 93 & 7 & 8 & 228 & 4 & 37 & 1853 & 1 & 67 \\
\hline 3 & 112 & 6 & 6 & 161 & 4 & 11 & 251 & 4 & 54 \\
\hline 4 & 132 & 6 & 8 & 111 & 9 & 60 & 3594 & $i$ & 44 \\
\hline 5 & 128 & 5 & 7 & 131 & 4 & 10 & 218 & 5 & 46 \\
\hline 6 & 75 & 8 & 8 & 177 & 5 & 38 & 1879 & 1 & 58 \\
\hline 7 & 162 & 5 & 7 & 189 & 4 & 14 & 413 & 3 & 59 \\
\hline 8 & 56 & 10 & 8 & 132 & 6 & 35 & 1746 & 2 & 46 \\
\hline \multicolumn{10}{|c|}{ 98CR14-A } \\
\hline 1 & 130 & 6 & 7 & 244 & 4 & 45 & 2403 & 1 & 69 \\
\hline 2 & 104 & 6 & 7 & 135 & 7 & 50 & 2805 & 1 & 47 \\
\hline 3 & 70 & 9 & 8 & 172 & 7 & 63 & 3771 & 1 & 55 \\
\hline 4 & 39 & 13 & 7 & 174 & 5 & 23 & 914 & 2 & 56 \\
\hline 5 & 64 & 9 & 7 & 183 & 5 & 33 & 1544 & 2 & 59 \\
\hline 6 & 95 & 7 & 8 & 182 & 5 & 32 & 1444 & 2 & 6] \\
\hline
\end{tabular}

LOD: linit of detection. speciation in the drip waters and saturation indices (SI values) of relevant minerals. The results are summarized in Table 6.

\section{Solids with SI $>0$ versus the observed minerals}

All water samples collected from dripping stalactites are supersaturated with at least two of the four compositions of jarosite-group minerals included in the WATEQ4F database: $\mathrm{KFe}_{3}^{3+}\left(\mathrm{SO}_{4}\right)_{2}(\mathrm{OH})_{6}$ and jarosite (ss), which corresponds to $\mathrm{K}_{0.77} \mathrm{Na}_{0.03}\left(\mathrm{H}_{3} \mathrm{O}\right)_{0.20} \mathrm{Fe}^{3+}{ }_{3}$ $\left(\mathrm{SO}_{4}\right)_{2}(\mathrm{OH})_{6}($ Alpers et al. 1989). Five of the six drip waters are also supersaturated with $\left(\mathrm{H}_{3} \mathrm{O}\right) \mathrm{Fe}^{3+}{ }_{3}$ $\left(\mathrm{SO}_{4}\right)_{2}(\mathrm{OH})_{6}$, and one is supersaturated with $\mathrm{NaFe}^{3+}{ }_{3}$ $\left(\mathrm{SO}_{4}\right)_{2}(\mathrm{OH})_{6}$. The pore water extracted from the mud is also close to saturation with $\mathrm{KFe}^{3+}{ }_{3}\left(\mathrm{SO}_{4}\right)_{2}(\mathrm{OH})_{6}$ and jarosite (ss). The saturated indices of jarosite-group minerals in equilibrium with the pore water are shown in Figure 8 and discussed below.

Goethite and some form of silica ("chalcedony", silica gel, or amorphous silica) are consistently supersaturated in all these waters. Mineralogical results indicate that an iron oxyhydroxide, probably goethite, is present. The predicted formation of amorphous silica is consistent with the SEM observations of silica coatings on crystals of the jarosite-group minerals. It is also consistent with the mass-balance calculation of Alpers et al. (1992); it indicates the precipitation of silica minerals resulting from reaction of the metavolcanic host-rock and oxidation of pyrite to produce the typical drainage-water at the Richmond mine. Secondary silica has also been found in tailings from other massive-sulfide deposits as a replacement of biotite (Jamieson et al. 1995). Initially, aluminosilicates will dissolve at low $\mathrm{pH}$; concentrations of dissolved silica will be expected to be particularly high in the hotter areas of the mine workings because of the exponential increase in silica solubility with increasing temperature (Rimstidt \& Barnes 1980, Fournier 1985). In the cooler areas of the mine (i.e., those near $30^{\circ} \mathrm{C}$ ), the silica precipitates. Nordstrom (1977) and Nordstrom \& Potter (1977) used the silica content of the Richmond mine effluent as a geothermometer based on the solubility of amorphous silica to predict that temperatures in the mine were at least $50^{\circ} \mathrm{C}$. Subsequent exploration of the mine workings since access became available in 1989 has yielded maximum observed temperatures of $48^{\circ} \mathrm{C}$ (Nordstrom \& Alpers 1999a).

\section{Calculated versus observed values of Eh}

The Eh calculated by WATEQ4F using the measured $\mathrm{Fe}^{2+} / \mathrm{Fe}^{3+}$ value is remarkably close to the Eh value measured in the Richmond mine at the time of sampling in the case of most samples (Table 6). The average calculated Eh is $770 \pm 75 \mathrm{mV}$ for the six samples of drip water, which is identical to the average measured $\mathrm{Eh}(770 \pm 77 \mathrm{mV})$. The Eh calculated from the $\mathrm{Fe}^{2+} / \mathrm{Fe}^{3+}$ 
TABLE 6. WATEQ4F RESULTS FOR DRIP WATER FROM STALACTITES AND MUD

\begin{tabular}{|c|c|c|c|c|c|c|c|}
\hline & $\begin{array}{c}98 \mathrm{CA} \\
105 \mathrm{~A}\end{array}$ & $\begin{array}{c}98 \mathrm{CA} \\
105 \mathrm{~B}\end{array}$ & $\begin{array}{c}98 \mathrm{CA} \\
105 \mathrm{D}\end{array}$ & $\begin{array}{c}98 \mathrm{CA} \\
105 \mathrm{E}\end{array}$ & $\begin{array}{c}98 \mathrm{CA} \\
105 \mathrm{~F}\end{array}$ & $\begin{array}{c}98 \mathrm{CA} \\
105 \mathrm{G}\end{array}$ & $\begin{array}{c}98 \mathrm{CA} \\
106\end{array}$ \\
\hline temperature $\left({ }^{\circ} \mathrm{C}\right)$ & 29.5 & 29.9 & 29.3 & 29.4 & 29.1 & 28.6 & 20 \\
\hline $\mathrm{pH}$ & 2.05 & 2.05 & 2.20 & 2.25 & 2.30 & 2.35 & 1.27 \\
\hline $\mathrm{Fe}^{2+} / \mathrm{Fe}^{3+}$ & 0.068 & 0.966 & 0.001 & 0.004 & 0.008 & 0.68 & 0.14 \\
\hline charge imbalance $(\%)$ & -4.13 & -8.16 & -2.45 & -15.75 & -21.72 & 0.19 & -18.19 \\
\hline Eh $(V)$ measured & 0.751 & 0.694 & 0.841 & 0.870 & 0.784 & 0.680 & 0.758 \\
\hline Eh calculated from $\mathrm{Fe}^{2+} / \mathrm{Fe}^{3+}$ & 0.751 & 0.682 & 0.866 & 0.826 & 0.805 & 0.692 & 0.711 \\
\hline Eh calculated from $\mathrm{As}^{3+i} \mathrm{As}^{5+}$ & 0.473 & 0.471 & 0.460 & 0.457 & 0.454 & 0.450 & n.c. \\
\hline supersaturated phases & $\begin{array}{c}\text { "chalcedony" } \\
\text { goethite } \\
\text { jarosite } \\
\text { hydronium } \\
\text { jarosite } \\
\text { jarosite } \\
\text { solid-solution } \\
\text { silica gel } \\
\mathrm{SiO}_{2}(\mathrm{a})\end{array}$ & $\begin{array}{l}\text { "chalcedony" } \\
\text { goethite } \\
\text { jarosite } \\
\text { jarosite } \\
\text { solid-solution } \\
\text { silica gel } \\
\mathrm{SiO}_{2}(\mathrm{a})\end{array}$ & $\begin{array}{l}\text { "chalcedony" } \\
\text { goethite } \\
\text { jarosite } \\
\text { hydronium } \\
\text { jarosite } \\
\text { jarosite } \\
\text { solid-solution } \\
\text { silica gel }\end{array}$ & $\begin{array}{c}\text { "chalcedony" } \\
\text { goethite } \\
\text { jarosite } \\
\text { hydronium } \\
\text { jarosite } \\
\text { jarosite } \\
\text { solid-solution } \\
\text { silica gel } \\
\mathrm{SiO}_{2} \text { (a) }\end{array}$ & $\begin{array}{l}\text { "chalcedony" } \\
\text { goethite } \\
\text { jarosite } \\
\text { hydronium } \\
\text { jarosite } \\
\text { natrojarosite } \\
\text { jarosite } \\
\text { solid-solution } \\
\text { silica gel } \\
\mathrm{SiO}_{2}(\mathrm{a})\end{array}$ & $\begin{array}{l}\text { "chalcedony" } \\
\text { goethite } \\
\text { jarosite } \\
\text { hydronium } \\
\text { jarosite } \\
\text { jarosite } \\
\text { solid-solution } \\
\text { silica gel } \\
\mathrm{SiO}_{2} \text { (a) }\end{array}$ & $\begin{array}{c}\text { "chalcedony" } \\
\text { goethite } \\
\text { silica gel } \\
\mathrm{SiO}_{2}(\mathrm{a})\end{array}$ \\
\hline
\end{tabular}

Observed phases in stalactite samples: jarosite, hydronium jarosite, natrojarosite, amorphous silica [ $\mathrm{SiO}_{2}$ (a)], and goethite. Composition of jarosite solid-solution: $\left[\mathrm{K}_{0.77} \mathrm{Na}_{0.03}\left(\mathrm{H}_{3} \mathrm{O}\right)_{0.20}\right] \mathrm{Fe}_{3}^{3+}\left(\mathrm{SO}_{4}\right)_{2}(\mathrm{OH})_{6}$ (Alpers et al. 1989, Ball et al. 1987). n.c.: not calculated.

of the pore water extracted from the mud $(714 \mathrm{mV})$ is slightly lower than that the measured $\mathrm{Eh}(758 \mathrm{mV})$. These results are expected because iron concentrations are high enough to provide an equilibrium potential at the platinum electrode surface (Nordstrom \& Alpers 1999b). The Eh calculated from the measured $\mathrm{As}^{3+} / \mathrm{As}^{5+}$ ratio ( $461 \pm 9 \mathrm{mV}$ for six drip-waters), on the other hand, is significantly different from the measured Eh value, although relatively constant from one sample to another. This result is also expected because this redox couple is generally not electro-active.

Calculated versus observed composition of the jarosite-group mineral for pore water in the mud

Following Alpers et al. (1989), the jarosite solidsolution $\mathrm{K}_{x} \mathrm{Na}_{y}\left(\mathrm{H}_{3} \mathrm{O}\right)_{(1-x-y)} \mathrm{Fe}_{3}\left(\mathrm{SO}_{4}\right)_{2}(\mathrm{OH})_{6}$ can be described by two compositional variables, $x$ and $y$. The following two dissolution reactions apply to the potassium ( $\mathrm{Kj}$ ) and sodium (Naj) components of the jarosite solid-solution, respectively:

$$
\begin{aligned}
& \mathrm{KFe}_{3}\left(\mathrm{SO}_{4}\right)_{2}(\mathrm{OH})_{6}+6 \mathrm{H}^{+} \leftrightarrow \\
& \mathrm{K}^{+}+3 \mathrm{Fe}^{3+}+2 \mathrm{SO}_{4}{ }^{2-}+6 \mathrm{H}_{2} \mathrm{O} \\
& \mathrm{NaFe}_{3}\left(\mathrm{SO}_{4}\right)_{2}(\mathrm{OH})_{6}+6 \mathrm{H}^{+} \leftrightarrow \\
& \mathrm{Na}^{+}+3 \mathrm{Fe}^{3+}+2 \mathrm{SO}_{4}{ }^{2-}+6 \mathrm{H}_{2} \mathrm{O}
\end{aligned}
$$

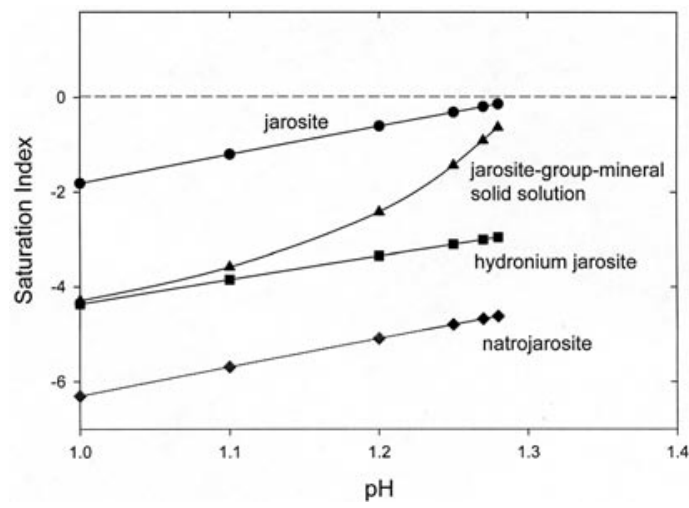

FIG. 8. Saturation indices calculated using WATEQ4F for the pore water 98CA106.

At equilibrium, the Gibbs free energy of the reactions is equal to 0 :

$$
\begin{aligned}
& \Delta_{\mathrm{f}} \mathrm{G}^{0} \mathrm{~K}^{+}+3 \Delta_{\mathrm{f}} \mathrm{G}^{0} \mathrm{Fe}^{3+}+2 \Delta_{\mathrm{f}} \mathrm{G}^{0} \mathrm{SO}_{4}^{2-} \\
& +6 \Delta_{\mathrm{f}} \mathrm{G}^{0} \mathrm{H}_{2} \mathrm{O}+\mathrm{RT} \ln (10)\left(\log \left[\mathrm{K}^{+}\right]\right. \\
& +3 \log \left[\mathrm{Fe}^{3+}\right]+2 \log \left[\mathrm{SO}_{4}{ }^{2-}\right]+6 \log \left[\mathrm{H}_{2} \mathrm{O}\right] \\
& +6 \mathrm{pH})-\Delta_{\mathrm{f}} \mathrm{G}_{\mathrm{Kj}}^{0}-\mathrm{RT} \ln (\mathrm{x})=0
\end{aligned}
$$




$$
\begin{aligned}
& \Delta_{\mathrm{f}} \mathrm{G}^{0} \mathrm{Na}^{+}+3 \Delta_{\mathrm{f}} \mathrm{G}^{0} \mathrm{Fe}^{3+}+2 \Delta_{\mathrm{f}} \mathrm{G}^{0} \mathrm{SO}_{4}{ }^{2-} \\
& +6 \Delta_{\mathrm{f}} \mathrm{G}^{0} \mathrm{H}_{2} \mathrm{O}+\mathrm{RT} \ln (10)\left(\log \left[\mathrm{Na}^{+}\right]\right. \\
& +3 \log \left[\mathrm{Fe}^{3+}\right]+2 \log \left[\mathrm{SO}_{4}^{2-}\right]+6 \log \left[\mathrm{H}_{2} \mathrm{O}\right] \\
& +6 \mathrm{pH})-\Delta_{\mathrm{f}} \mathrm{G}^{0}{ }_{\text {Naj }}-\mathrm{RT} \ln (\mathrm{y})=0
\end{aligned}
$$

In equations (3) and (4), $\Delta_{\mathrm{f}} \mathrm{G}^{0}{ }_{\mathrm{i}}$ refers to the standardstate Gibbs free energy of formation of species $i$, and square brackets denote aqueous activity. The logarithms of individual ion activity-products (IAP) for jarosite and natrojarosite are defined, based on equations (3) and (4), as:

$$
\begin{aligned}
& \log \left[\mathrm{IAP}_{\mathrm{Kj}}\right]=\log \left[\mathrm{K}^{+}\right]+3 \log \left[\mathrm{Fe}^{3+}\right] \\
& +2 \log \left[\mathrm{SO}_{4}{ }^{2-}\right]+6 \log \left[\mathrm{H}_{2} \mathrm{O}\right]+6 \mathrm{pH} \\
& \log \left[\mathrm{IAP}_{\mathrm{Naj}}\right]=\log \left[\mathrm{Na}^{+}\right]+3 \log \left[\mathrm{Fe}^{3+}\right] \\
& +2 \log \left[\mathrm{SO}_{4}{ }^{2-}\right]+6 \log \left[\mathrm{H}_{2} \mathrm{O}\right]+6 \mathrm{pH}
\end{aligned}
$$

The solubility products of jarosite and natrojarosite are related to the standard-state Gibbs free energies of formation:

$$
\begin{aligned}
& \text { RT } \ln (10) \log \mathrm{K}_{\mathrm{sp}-\mathrm{Kj}}=\Delta_{\mathrm{f}} \mathrm{G}^{0} \mathrm{Kj}_{-}-\Delta_{\mathrm{f}} \mathrm{G}^{0} \mathrm{~K}^{+} \\
& -3 \Delta_{\mathrm{f}} \mathrm{G}^{0} \mathrm{Fe}^{3+}-2 \Delta_{\mathrm{f}} \mathrm{G}^{0} \mathrm{SO}_{4}{ }^{2-}-6 \Delta_{\mathrm{f}} \mathrm{G}^{0}{ }_{\mathrm{H}_{2} \mathrm{O}} \\
& \text { RT } \ln (10) \log \mathrm{K}_{\mathrm{sp}-\mathrm{Naj}}=\Delta_{\mathrm{f}} \mathrm{G}^{0}{ }_{\mathrm{Naj}}-\Delta_{\mathrm{f}} \mathrm{G}^{0}{ }_{\mathrm{Na}^{+}} \\
& -3 \Delta_{\mathrm{f}} \mathrm{G}^{0} \mathrm{Fe}^{3+}-2 \Delta_{\mathrm{f}} \mathrm{G}^{0} \mathrm{SO}_{4}{ }^{2-}-6 \Delta_{\mathrm{f}} \mathrm{G}^{0}{ }_{\mathrm{H}_{2} \mathrm{O}}
\end{aligned}
$$

Combining equations (3) to (8) produces:

$$
\begin{aligned}
& \log \left[\mathrm{IAP}_{\mathrm{Kj}}\right]-\log \mathrm{K}_{\mathrm{sp}-\mathrm{Kj}}-\log (\mathrm{x})=0 \\
& \log \left[\mathrm{IAP}_{\text {Naj }}\right]-\log \mathrm{K}_{\mathrm{sp}-\mathrm{Naj}}-\log (\mathrm{y})=0
\end{aligned}
$$

Given chemical data for a water sample and assuming ideal mixing in jarosite solid-solution, equations (9) and (10) can be used to calculate $x$ and $y$, which represent the composition of the ideal jarosite solidsolution in equilibrium with that water sample. The values of $\log \left[\mathrm{IAP}_{\mathrm{i}}\right]$ and $\log \mathrm{K}_{\mathrm{sp}-\mathrm{i}}$ were calculated using WATEQ4F. Thermodynamic data for jarosite at $25^{\circ} \mathrm{C}$ $\left(\log \mathrm{K}_{\mathrm{sp}}\right)$ were based on experimental data of Kashkay et al. (1975) and Baron \& Palmer (1996). The temperature dependence of $\log \mathrm{K}_{\mathrm{sp}}\left(\Delta \mathrm{H}^{\circ}\right)$ was taken from Ball et al. (1987).

The values of $x$ and $y$ were also obtained assuming non-ideal mixing of $\mathrm{K}$ and $\mathrm{Na}$, and of $\mathrm{Na}$ and $\mathrm{H}_{3} \mathrm{O}$, in the jarosite-group-mineral structure $\left(\mathrm{W}_{\mathrm{K}-\mathrm{Na}}=\mathrm{W}_{\mathrm{H}_{3} \mathrm{O}-\mathrm{Na}}\right.$ $\left.=1.275 \mathrm{~kJ} \bullet \mathrm{mol}^{-1} ; \mathrm{W}_{\mathrm{H}_{3} \mathrm{O}-\mathrm{K}}=0\right)$. Alpers et al. $(1989)$ suggested ideal mixing of $\mathrm{K}$ and $\mathrm{H}_{3} \mathrm{O}$ in jarosite solidsolution, but warned of probable non-ideality of $\mathrm{K}-\mathrm{Na}$ and $\mathrm{Na}-\mathrm{H}_{3} \mathrm{O}$ substitution based on differences in unitcell volume. The value of $1.275 \mathrm{~kJ}^{\circ} \mathrm{mol}^{-1}$ is estimated as a maximum value compatible with the experimental data summarized by Stoffregen et al. (2000) for the jarosite-natrojarosite binary join. In that case, equations (9) and (10) contain additional terms accounting for the non-ideality, and the equations could only be solved by a numerical method. (The Generalized Reduced Gradient technique of nonlinear optimization utilized in Microsoft ${ }^{\circledR}$ Excel 97 was used in this study.) The results of calculations assuming ideal and non-ideal mixing of $\mathrm{K}-\mathrm{Na}$ and $\mathrm{Na}-\mathrm{H}_{3} \mathrm{O}$ were found to be virtually identical, owing to the negligible amount of $\mathrm{Na}$ in the calculated compositions of the jarosite-group minerals.

Using the method described above, the composition of the jarosite-group mineral in equilibrium with the pore water extracted from the jarosite mud (sample 98CA106) was calculated for a range of $\mathrm{pH}$ values near the measured value of 1.27 . The calculated $\mathrm{Na}$ content is so low that the jarosite-group minerals can effectively be considered as members of the solid-solution between the $\mathrm{K}$ and $\mathrm{H}_{3} \mathrm{O}$ end-members. The value of $x$, representing the $\mathrm{K}$ end-member, varies from 0.1 at $\mathrm{pH}=1.1$ to 0.7 at $\mathrm{pH}=1.28$. A small change in $\mathrm{pH}$ produces significant change in the $\mathrm{K}^{+}$content of the calculated composition. This effect is expected because a small change in $\mathrm{pH}$ at values near 1.27 represents a large change in aqueous proton (and hydronium ion) concentration and activity.

The calculated equilibrium Na content of the jarosite-group minerals in equilibrium with water samples 98WA105(A, B, D, E, F, and G) and 98WA106 is low in comparison with the observed values (Table 4). A decrease of about $12 \mathrm{~kJ} / \mathrm{mol}$ in the $\Delta_{\mathrm{f}} \mathrm{G}^{0}$ of natrojarosite would be required to reproduce the observed $\mathrm{Na}$ contents. This change in free energy is within the range of uncertainty for recent estimates of the $\Delta_{\mathrm{f}} \mathrm{G}^{0}$ of natrojarosite (Stoffregen et al. 2000, Drouet \& Navrotsky 2003, Drouet et al. 2004).

\section{Saturation indices for calculated compositions of the jarosite solid-solution}

The saturation index was computed for calculated compositions of jarosite-group mineral solid-solution (noted as jgm-ss) based on the following dissolutionreaction (Alpers et al. 1989):

$$
\begin{aligned}
& \mathrm{K}_{x} \mathrm{Na}_{y}\left(\mathrm{H}_{3} \mathrm{O}\right)_{(1-x-y)} \mathrm{Fe}_{3}\left(\mathrm{SO}_{4}\right)_{2}(\mathrm{OH})_{6} \\
& +(5+x+y) \mathrm{H}^{+} \leftrightarrow x \mathrm{~K}^{+}+y \mathrm{Na}^{+}+3 \mathrm{Fe}^{3+} \\
& +2 \mathrm{SO}_{4}^{2-}+(7-x-y) \mathrm{H}_{2} \mathrm{O}
\end{aligned}
$$

The logarithm of the ion activity-product (IAP) for reaction (11) can be expressed as:

$$
\begin{aligned}
& \log \left[\mathrm{IAP}_{\text {jgm-ss }}\right]=x \log \left[\mathrm{K}^{+}\right]+y \log \left[\mathrm{Na}^{+}\right] \\
& +3 \log \left[\mathrm{Fe}^{3+}\right]+2 \log \left[\mathrm{SO}_{4}^{2-}\right] \\
& +(7-x-y) \log \left[\mathrm{H}_{2} \mathrm{O}\right]+(5+x+y) \mathrm{pH}
\end{aligned}
$$

The logarithm of the solubility-product constant $\mathrm{K}_{\mathrm{sp}-\mathrm{jgm}-\mathrm{ss}}$ can be calculated for each composition of jarosite-group mineral solid-solution as:

$$
\ln \mathrm{K}_{\mathrm{sp}-\mathrm{jgm}-\mathrm{ss}}=\Delta_{\mathrm{r}} \mathrm{G}^{0}{ }_{11} / \mathrm{RT}
$$


where $\Delta_{\mathrm{r}} \mathrm{G}_{11}$ is calculated as:

$$
\begin{aligned}
& \Delta_{\mathrm{r}} \mathrm{G}_{11}=\mathrm{x} \Delta_{\mathrm{f}} \mathrm{G}_{\mathrm{K}-\mathrm{J}}^{0}+\mathrm{y} \Delta_{\mathrm{f}} \mathrm{G}^{0}{ }_{\mathrm{Na}-\mathrm{J}}+(1-x-y) \\
& \Delta_{\mathrm{f}} \mathrm{G}^{0} \mathrm{H}_{\mathrm{H}} \mathrm{O}-\mathrm{J}+\mathrm{RT}[x \ln (x)+y \ln (y)+(1-x-y) \\
& \ln (1-x-y)]-x \Delta_{\mathrm{f}} \mathrm{G}^{0} \mathrm{~K}^{+}-y \Delta_{\mathrm{f}} \mathrm{G}^{0} \mathrm{Na}^{+}-3 \Delta_{\mathrm{f}} \mathrm{G}^{0} \mathrm{Fe}^{3+} \\
& -2 \Delta_{\mathrm{f}} \mathrm{G}^{0} \mathrm{SO}_{4}^{2-}-(7-x-y) \Delta_{\mathrm{f}} \mathrm{G}^{0}{ }_{\mathrm{H}_{2} \mathrm{O}}
\end{aligned}
$$

The equations (12) to (14) are used to obtain the saturation index SI:

$$
\mathrm{SI}=\log \left(\mathrm{IAP}_{\mathrm{jgm}-\mathrm{ss}} / \mathrm{K}_{\mathrm{sp}-\mathrm{jgm}-\mathrm{ss}}\right)
$$

or

$$
\begin{aligned}
& \mathrm{SI}=x \log \left[\mathrm{IAP}_{\mathrm{Kj}}\right]+y \log \left[\mathrm{IAP}_{\mathrm{Naj}}\right]+(1-x-y) \\
& \log \left[\mathrm{IAP}_{\mathrm{Hj}}\right]-x \log \mathrm{K}_{\mathrm{sp}-\mathrm{Kj}}-y \log \mathrm{K}_{\mathrm{sp}-\mathrm{Naj}} \\
& -(1-x-y) \log \mathrm{K}_{\mathrm{sp}-\mathrm{Hj}}-x \log (\mathrm{x})-y \log (\mathrm{y}) \\
& -(1-x-y) \log (1-x-y)
\end{aligned}
$$

where

RT $\ln (10) \log \mathrm{K}_{\text {sp- } \mathrm{Hj}}=\Delta_{\mathrm{f}} \mathrm{G}_{\mathrm{Hj}}^{0}-3 \Delta_{\mathrm{f}} \mathrm{G}^{0} \mathrm{Fe}^{3+}$ $-2 \Delta_{\mathrm{f}} \mathrm{G}^{0} \mathrm{SO}_{4}^{2-}-7 \Delta_{\mathrm{f}} \mathrm{G}^{0}{ }_{\mathrm{H}_{2} \mathrm{O}}$

and

$\log \left[\mathrm{IAP}_{\mathrm{Hj}}\right]=3 \log \left[\mathrm{Fe}^{3+}\right]+2 \log \left[\mathrm{SO}_{4}{ }^{2-}\right]$

$+7 \log \left[\mathrm{H}_{2} \mathrm{O}\right]+5 \mathrm{pH}$,

by analogy with equations (5) - (8).

Equation (15) was used for SI calculations. As in the case of the calculation of the composition of the jarositegroup minerals, the values of $\log \left[\mathrm{IAP}_{\mathrm{i}}\right]$ and $\log \mathrm{K}_{\mathrm{sp}-\mathrm{i}}$ were calculated using WATEQ4F and the thermodynamic data of Kashkay et al. (1975), Baron \& Palmer (1996), and Ball et al. (1987).

Saturation indices (SI) for the jarosite-group minerals were calculated for the pore-water composition 98CA106 for a range a $\mathrm{pH}$ values (Fig. 8). The SI values for jarosite and the jarosite-group mineral solid-solution approach zero near the measured $\mathrm{pH}$ of 1.27 . The water is consistently undersaturated with respect to the endmember compositions of natrojarosite and hydronium jarosite over the range of $\mathrm{pH}$ values tested.

\section{DisCUSSION AND CONCLUSION}

The waters that precipitate abundant jarosite-group minerals in the D drift are less acidic and more dilute than the waters found elsewhere in the Richmond mine, including those that precipitated abundant magnesiocopiapite collected a few meters away from the samples of jarosite-group mineral (Jamieson et al. 2005).

Geochemical modeling using WATEQ4F indicates that the stalactite drip-waters are supersaturated, and the pore water of the mud sample is at or close to equilibrium with the solid phases observed. Jarositegroup minerals are known to precipitate directly from aqueous solution in the field (Nordstrom 1977), in the lab (Alpers et al. 1989), and in process solutions (Dutrizac \& Jambor 2000).

Nordstrom et al. (2000) described the chemical evolution of extremely acidic mine-waters at Iron Mountain as the result of four hydrobiogeochemical processes: (1) generation of acidic ferrous sulfate solutions by pyrite oxidation, (2) concentration of ions by evaporation, (3) consumption of $\mathrm{H}^{+}$during oxidation of $\mathrm{Fe}^{2+}$ to $\mathrm{Fe}^{3+}$ at very low $\mathrm{pH}$, and (4) acid production or consumption during mineral precipitation, depending on the stoichiometry of the Fe sulfate precipitating. In the part of the D drift where jarosite-group precipitates were found, there may be considerably less evaporative concentration (process 2) than elsewhere in the mine workings because of the addition of cool, dilute groundwater from the adjacent host felsic metavolcanic rock and a lower temperature as a result of less exothermic reaction (pyrite oxidation). Consequently, the $\mathrm{pH}$ is not as low as elsewhere in the mine workings. If the waters associated with jarosite-group minerals were concentrated by evaporation, they would approach the composition of the extremely Fe-rich, acidic $(\mathrm{pH}$ $=-0.9$ ) water coexisting with magnesiocopiapite (Robinson et al. 2000, Jamieson et al. 2005). At the $\mathrm{pH}$ values observed, $\mathrm{Fe}^{3+}$ produced by process (3) is hydrolyzed and then precipitated as jarosite-group minerals and goethite, whereas for other waters in the mine that have $\mathrm{pH}$ values less than $2, \mathrm{Fe}^{3+}$ hydrolysis is minimal. In theory, the precipitation of jarosite and natrojarosite releases acidity to solution. The amount of acid released is reduced proportionally, however, by the amount of $\mathrm{H}_{3} \mathrm{O}$-bearing jarosite precipitating, according to the reversal of equation (11).

The measured compositions and X-ray maps of the samples of jarosite-group minerals from the Richmond mine indicate that there is a significant range of $\mathrm{Na}-, \mathrm{K}-$ and $\mathrm{H}_{3} \mathrm{O}$-dominant components present in the samples. The compositions include hydronium jarosite, in which a maximum of $62 \%$ of the $\mathrm{D}$ site is occupied by $\mathrm{H}_{3} \mathrm{O}$. The apparent $\mathrm{H}_{3} \mathrm{O}$-rich compositions are richer in $\mathrm{H}_{3} \mathrm{O}$ relative to most jarosite-group minerals reported in the literature from mine-waste sites (Dutrizac \& Jambor 2000). This enrichment may exist because they are precipitated from rapidly oxidizing water at $\mathrm{pH}$ values lower than those associated with many acid sulfate waters. According to equilibrium calculations, the $\mathrm{K}$ : $\mathrm{H}_{3} \mathrm{O}$ ratio in jarosite-group minerals should depend strongly on $\mathrm{pH}$. In the case of the pore water in the mud sample, we demonstrated that the observed range in composition of the solid can be accounted for by a small range in $\mathrm{pH}$ (Fig. 8) or by changes in aqueous concentration of $\mathrm{K}$ (or both). The variation in $\mathrm{pH}$ corresponding to the range of observed compositions of the jarosite solid-solution is similar to the uncertainty 
associated with measuring the $\mathrm{pH}$ (approximately 0.1 log unit), but the compositional range indicates an actual change in solution composition.

\section{ACKNOWLEDGEMENTS}

Funding for this research was provided, in part, from NSERC grants to HEJ. HEJ and CR also thank R.C. Peterson at Queen's for help with the XRD, and P.L. Roeder and D. Kempson for help with EMPA. J.L. Campbell and Z. Nejedly at University of Guelph helped with the micro-PIXE analysis. M.P. Hunerlach at USGS, Sacramento, assisted with the field and laboratory work. G. Desborough at USGS, Denver, assisted with XRD. D.K. Nordstrom acknowledges the support of the U.S. Geological Survey National Research Program, Water Resources Discipline. All the authors are grateful to Region 9 of the USEPA, especially the Superfund Project Site Manager, Rick Sugarek, for facilitating mine access and providing funding for a portion of this research. The manuscript was improved by the review of Dr. Uwe Kolitsch and an anonymous reviewer, as well as the comments of Associate Editor D. Paktunc and Editor R.F. Martin. The use of brand names and trademarks in this paper does not constitute endorsement by the U.S. Geological Survey.

\section{REFERENCES}

Alpers, C.N. \& Brimhall, G.H (1989): Paleohydrologic evolution and geochemical dynamics of cumulative supergene metal enrichment at La Escondida, Atacama Desert, northern Chile. Econ. Geol. 84, 229-255.

, Nordstrom, D.K. \& BALL, J.W. (1989): Solubility of jarosite solid solutions precipitated from acid mine waters, Iron Mountain, California, U.S.A. Sciences Géologiques, Bull. 42, 281-298.

\& BURCHARD, J. (1992): Compilation and interpretation of water-quality and discharge data for acidic mine waters from Iron Mountain, California 1940-91. U.S. Geol. Surv., Water-Resources Invest. Rep. 91-4160.

\& SPITZley, J. (2003): Extreme acid mine drainage from a pyritic massive sulfide deposit: the Iron Mountain end-member. In Environmental Aspects of Mine Wastes (J.L. Jambor, D.W. Blowes \& A.I.M. Ritchie, eds.). Mineral. Assoc. Can., Short Course Vol. 31, 407-430.

\& Thompson, J.M. (1994): Seasonal variations of $\mathrm{Zn} / \mathrm{Cu}$ ratios in acid mine water from Iron Mountain, California. In Environmental Geochemistry of Sulfide Oxidation (C.N. Alpers \& D.W. Blowes, eds.). Am. Chem. Soc., Symp. Ser. 550, 324-344.

Ball, J.W., Nordstrom, D.K. \& Zachmann, D.W. (1987): WATEQ4F. A personal computer FORTRAN translation of the geochemical model WATEQ2 (with revised database, 1999). U.S. Geol. Surv., Open File Rep. 87-50.

BARON, D. \& PALMER, C.D. (1996): Solubility of jarosite at 4-35 ${ }^{\circ}$ C. Geochim. Cosmochim. Acta 60, 185-195.

BighaM, J.M. (1994): Mineralogy of ochre deposits formed by sulfide oxidation. In The Environmental Geochemistry of Sulfide Mine-Wastes (J.L. Jambor \& D.W. Blowes, eds.). Mineral. Assoc. Can., Short Course Vol. 22, 103-132.

\& NoRDSTROM, D.K. (2000): Iron and aluminum hydroxysulfates from acid sulfate waters. In Sulfate Minerals: Crystallography, Geochemistry, and Environmental Significance (C.N. Alpers, J.L. Jambor \& D.K. Nordstrom, eds.). Rev. Mineral. Geochem. 40, 351-393.

Brophy, G.P. \& SHERIDAN, M.F. (1965): Sulfate studies. IV. The jarosite - natrojarosite - hydronium jarosite solid solution series. Am. Mineral. 50, 1595-1607.

CABRI, L.J. \& CAMPBell, J.L. (1998): The proton microprobe in ore mineralogy (micro-PIXE technique). In Modern Approaches to Ore and Environmental Mineralogy (L.J. Cabri \& D.J. Vaughan, eds.) Mineral. Assoc. Can., Short Course Vol. 27, 181-198.

DOYLE, J.H. \& ChAmBers, W.F. (1981): ZAF80: an improved quantitative analysis for the Flextran language system. Rockwell International, RFP-3215.

Drouet, C. \& Navrotsky, A. (2003): Synthesis, characterization, and thermochemistry of $\mathrm{K}-\mathrm{Na}-\mathrm{H}_{3} \mathrm{O}$ jarosites. Geochim. Cosmochim. Acta 67, 2063-2076.

Pass, K.L., Baron, D., Draucker, S. \& NAVRotsky, A. (2004): Thermochemistry of jarosite - alunite and natrojarosite - natroalunite solid solutions. Geochim. Cosmochim. Acta 68, 2197-2205.

DutrizAC, J.E. \& JAMBOR, J.L. (2000): Jarosites and their application in hydrometallurgy. In Sulfate Minerals: Crystallography, Geochemistry, and Environmental Significance (C.N. Alpers, J.L. Jambor \& D.K. Nordstrom, eds.). Rev. Mineral. Geochem. 40, 405-443.

Edwards, K.J., Bond, P.L., Gihring, T.M. \& BANFIELD, J.F. (2000): An Archaean iron-oxidizing extreme acidophile important in acid mine drainage. Science 287, 1796-1799.

FOURNIER, R.O. (1985): The behavior of silica in hydrothermal systems. In Geology and Geochemistry of Epithermal Systems (B.R. Berger \& P.M. Bethke, eds.). Rev. Econ. Geol. 2, 45-62.

HÄrtig, C., BRAnd, P. \& Bohmhammel, K. (1984): Fe-Allomorphie und Strukturwasser in Kristallen von Jarosit-Alunit-Typ. Z. Anorg. Allg. Chem. 508, 159-164.

Hochella, M.F., JR., Moore, J.N., Putnis, C.V., Putnis, A., KASAMA, T. \& EBERL, D.D. (2005): Direct observation of heavy metal - mineral association from the Clark Fork River Superfund Complex: implications for metal trans- 
port and bioavailability. Geochim. Cosmochim. Acta $\mathbf{6 9}$, $1651-1663$.

Hunt, J.B., Clift, P.D., Lacasse, C., Vallier, T.L. \& WerNER, R. (1998): Interlaboratory comparison of electron microprobe analysis of glass geochemistry. In Scientific Results (A.D. Saunders, H.C. Larsen \& S.W. Wise, Jr., eds.). Proc. Ocean Drilling Program 152, 85-90.

\& HiLl, P.G. (1993): Tephra geochemistry: a discussion of some persistent analytical problems. Holocene 3, 271-278.

JAMBOR, J.L. (1994): Mineralogy of sulfide-rich tailings and their oxidation products. In Environmental Geochemistry of Sulfide Mine-Wastes (J.L. Jambor \& D.W. Blowes, eds.). Mineral. Assoc. Can., Short Course Vol. 22, 59-102.

(1999): Nomenclature of the alunite supergroup. Can. Mineral. 37, 1323-1341.

Nordstrom, D.K. \& AlPers, C.N. (2000): Metalsulfate salts from sulfide mineral oxidation. In Sulfate Minerals: Crystallography, Geochemistry, and Environmental Significance (C.N. Alpers, J.L. Jambor \& D.K. Nordstrom, eds.). Rev. Mineral. Geochem. 40, 303-350.

Jamieson, H.E., Nordstrom, D.K., AlPers, C.N. \& Peterson, R.C. (1999): The incorporation of toxic elements in iron sulfates precipitated from acid mine waters. In Sudbury '99: Mining and the Environment II (D. Goldsack, N. Belzile, P. Yearwood \& G. Hall, eds.). 1, 231-241.

Robinson, C., Alpers, C.N., McCleskey, R.B., Nordstrom, D.K. \& Peterson, R.C. (2005): Major and trace element composition of copiapite-group minerals and coexisting water from the Richmond mine, Iron Mountain, California. Chem. Geol. 215, 387-405.

Shaw, S.C. \& Clark, A.H. (1995): Mineralogical factors controlling metal release at GECO, Manitouwadge, Ontario. In Sudbury '95: Mining and the Environment (T.P. Hynes \& M.C. Blanchette, eds.). 1, 405-415.

JCPDS (Joint Committee on Powder Diffraction Standards) (1997): Mineral Powder Diffraction File. International Centre for Diffraction Data, Swarthmore, Pennsylvania.

KashKay, C.M., Borovskaya, Y.B. \& Babazade, M.A. (1975): Determination of $\Delta \mathrm{G}_{\mathrm{f}, 298}^{\mathrm{o}}$ of synthetic jarosite and its sulfate analogues. Geochem. Int. 12, 115-121.

Kinkel, A.R., Hall, W.E. \& Albers, J.P. (1956): Geology and base-metal deposits of West Shasta copper-zinc district, Shasta County, California. U.S. Geol. Surv., Prof. Pap. 285.

Kubisz, J. (1961): Natural hydronium jarosite. Bull. Acad. Polon. Sci., Ser. Sci. Geol. Geogr. 8, 1-10.

Majzlan, J., Stevens, R., Boerio-Goates, J., Woodfield, B.R., Navrotsky, A., Burns, P.C., Crawford, M.K. \& Amos, T.G. (2004): Thermodynamic properties, low-temperature heat-capacity anomalies, and single-crystal X-ray refinement of hydronium jarosite, $\left(\mathrm{H}_{3} \mathrm{O}\right) \mathrm{Fe}_{3}\left(\mathrm{SO}_{4}\right)_{2}(\mathrm{OH})_{6}$. Phys. Chem. Minerals 31, 518-531.

MAKITA, S.N. \& FuJII, R. (1992): Quality assurance practices of the U.S. Geological Survey laboratory in Sacramento, California. U.S. Geol. Surv., Open-File Rep. 91-522.

Munsell Color Company, Inc. (1954): Munsell ${ }^{\circledR}$ Soil Color Charts. Baltimore, Maryland, USA.

NoRDSTROM, D.K. (1977): Hydrogeochemical and Microbiological Factors Affecting the Heavy Metal Geochemistry of an Acid Mine Drainage System. Ph.D. thesis, Stanford Univ., Stanford, California, USA.

\& ALPERS, C.N. (1995): Remedial investigations, decisions, and the geochemical consequences at Iron Mountain mine, California. In Sudbury '95: Mining and the Environment (T.P. Hynes \& M.C. Blanchette, eds.). 1, 633-642.

$\&$ (1999a): Negative pH, efflorescent mineralogy, and consequences for environment restoration at the Iron Mountain Superfund site, California. In Geology, Mineralogy, and Human Welfare (J.V. Smith, P.R. Buseck \& M. Ross, eds.). Proc. Nat. Acad. Sci. 96, 3455-3462.

$\&$ (1999b): Geochemistry of acid mine waters. In The Environmental Geochemistry of Mineral Deposits (G.S. Plumlee \& M.J. Logsdon, eds.). Rev. Econ. Geol. 6A, 133-160.

PtaceK, C.J. \& Blowes, D.W. (2000) Negative $\mathrm{pH}$ and extremely acidic mine waters from Iron Mountain, California. Env. Sci. Tech. 34, 254-258.

\& PotTER, R.W., II (1977): The interactions between acid mine water and rhyolite. Proc. Second Int. Symp. on Water-Rock Interaction (Strasbourg), I-15 - I-26.

Paktunc, D. \& Dutrizac, J.E. (2003): Characterization of arsenate-for-sulfate substitution in synthetic jarosite using $\mathrm{X}$-ray diffraction and X-ray absorption spectroscopy. Can. Mineral. 41, 905-919.

RimstidT, J.D. \& BARNES, H.L. (1980): The kinetics of silica water reactions. Geochim. Cosmochim. Acta 44, 16831699.

Ripmeester, J.A., RATClifFe, C.I., DutrizaC, J.E. \& JAMBOR, J.L. (1986): Hydronium ion in the alunite-jarosite group. Can. Mineral. 24, 435-447.

Robbins, E.I., Rodgers, T.M., Alpers, C.N. \& Nordstrom, D.K. (2000): Ecogeochemistry of the subsurface food web at $\mathrm{pH}$ 0-2.5 in Iron Mountain, California, USA. Hydrobiologia 433, 15-23.

Robinson, C., Jamieson, H.E., Alpers, C.N. \& Nordstrom, D.K. (2000): The composition of co-existing jarosite and water from the Richmond mine, Iron Mountain, CA. Geol. Soc. Am., Abstr. Programs 32, A101. 
Robinson, I.C. (2000): The Role of Jarosite and Copiapite in the Chemical Evolution of Acid Drainage Waters, Richmond Mine, Iron Mountain, California. M.Sc. thesis, Queen's University, Kingston, Ontario.

SAvAGE, K.S., BIRD, D.K. \& O'DAY, P.A. (2005): Arsenic speciation in synthetic jarosite. Chem. Geol. 215, 473-493.

ScotT, K.M. (1987) Solid solution in, and classification of, gossan-derived members of the alunite-jarosite family, northwest Queensland, Australia. Am. Mineral. 72, 178187.

StOFFrEgen, R.E. \& AlPERS, C.N. (1987): Woodhouseite and svanbergite in hydrothermal ore deposits: products of apatite destruction during advanced argillic alteration. Can. Mineral. 25, 201-211.

\& JAMBOR, J.L. (2000): Alunite-jarosite crystallography, thermodynamics and geochronology. In Sulfate Minerals: Crystallography, Geochemistry and Environmental Significance (C.N. Alpers, J.L. Jambor \& D.K. Nordstrom, eds.). Rev. Mineral. Geochem. 40, 454-475.
STOOKEy, L.L. (1970): Ferrozine - a new spectrophotometric reagent for iron. Anal. Chem. 42, 779-781.

To, T.B., Nordstrom, D.K., Cunningham, K.M., Ball, J.W. \& MCCLESKEY, R.B. (1999): New method for the direct determination of $\mathrm{Fe}(\mathrm{III})$ concentration in acid mine waters. Env. Sci. Tech. 33, 807-813.

Van Everdingen, R.O., Shakur, M.A. \& Michel, F.A. (1985): Oxygen- and sulfur-isotope geochemistry of acidic groundwater discharge in British Columbia, Yukon and the District of Mackenzie, Canada. Can. J. Earth Sci. 22, 1689-1695.

Zoтov, A.V. (1970): Jarosite in sediments from thermal waters of Kunashir Island. In Mineralogy of the Hydrothermal Systems of Kamchatka and Kurile Islands (S.I. Naboka, ed.). Nauka, Moscow, USSR (in Russ.; 165-187).

Received March 11, 2004, revised manuscript accepted September 15, 2005. 